\title{
Nicotinic Ligands as Multifunctional Agents for the Treatment of Neuropsychiatric Disorders
}

\begin{abstract}
Alvin V. Terry, Jr, Patrick M. Callahan, and Caterina M. Hernandez.
Department of Pharmacology and Toxicology, Georgia Regents University, Augusta, Georgia, 30912
\end{abstract}

Running Title: Nicotinic Ligands as Multifunctional Agents

\section{Corresponding Author:}

Alvin V. Terry Jr., Ph.D.

Regents Professor and Chair

Department of Pharmacology and Toxicology

Georgia Regents University

1120 Fifteenth Street, CB-3545

Augusta, Georgia 30912-2450

Phone 706-721-9462

Fax 706-721-2347

e-mail: aterry@ gru.edu 


\begin{abstract}
The challenges associated with developing more effective treatments for neurologic and psychiatric illness such as Alzheimer's disease and schizophrenia are considerable. Both the symptoms and the pathophysiology of these conditions are complex and poorly understood and the clinical presentations across different patients can be very heterogeneous. Moreover, it has become apparent that the reductionist approach to drug discovery for these illnesses that has dominated the field for decades (i.e., the development of highly selective compounds or other treatment modalities focused on a very specific pathophysiologic target) has not been widely successful. Accordingly, a variety of new strategies have emerged including the development of "multitarget-directed ligands" (MTDLs), the development and/or identification of compounds that exhibit "multifunctional" activity (e.g., pro-cognitive plus neuroprotective, pro-cognitive plus antipsychotic activity), "repurposing" strategies for existing compounds that have other clinical indications, and novel "adjunctive" treatment strategies that might enhance the efficacy of the currently available treatments. Interestingly, a variety of ligands at nicotinic acetylcholine receptors (nAChRs) appear to have the potential to fulfill one or more of these desirable properties (i.e., multifunctional, repurposing, or adjunctive treatment potential). The purpose of this review (while not all-inclusive) is to provide an overview of a variety of $\mathrm{nAChR}$ ligands that demonstrate potential in these categories, particularly, "multifunctional" properties. Due to their densities in the mammalian brain and the amount of literature available, the review will focus on ligands of the high affinity $\alpha 4 \beta 2 \mathrm{nAChR}$ and the low affinity $\alpha 7 \mathrm{nAChR}$.
\end{abstract}

Key Words: Alzheimer's disease, Mild Cognitive Impairment, schizophrenia, cholinergic, memory 
Abbreviations: AChE, acetylcholinesterase; AD, Alzheimer's Disease; DMTS, Delayed Match to Sample; MLA, methyllycaconitine; NHP, non-human primate, NOR, spontaneous novel object recognition 


\section{Introduction}

The rising prevalence of neuropsychiatric illnesses is a major public health concern while at the same time, research and development $(\mathrm{R} \& \mathrm{D})$ for new drugs to treat these conditions is declining and many pharmaceutical companies have abandoned this field of research altogether $[1,2]$. There are a number of cited reasons for this decline in $R \& D$ and they include the low success rate for clinical approval of novel treatments, increased time and costs associated with the regulatory burden, litigation-related concerns with drugs that do reach the market, and the wider availability of generic drugs which reduces profits for companies that heavily invest in R\&D [3]. Even during the most aggressive periods of R\&D in the last 15 years, there has been a paucity of truly new chemical entities developed in the pharmaceutical industry [4] and this has been particularly apparent in the field of neurology and psychiatry.

It has also become increasingly evident that the reductionist approach to modern drug discovery that has dominated the field for decades (i.e., the development of highly selective compounds or other treatment modalities focused on a very specific pathophysiologic target) has not been widely successful [5], especially for the treatment of neuropsychiatric disorders [6]. Accordingly, a number of alternative approaches to drug discovery have emerged and they include the development of "multitarget-directed ligands" (MTDLs) "multifunctional" compounds, "repurposing" strategies, and novel "adjunctive" treatment strategies. Given the complexity of both the pathophysiology and symptom profile of conditions such as Alzheimer's disease (AD) and schizophrenia, it would appear rational to attempt to develop compounds that modulate several therapeutic targets simultaneously (i.e., the MTDL approach) and/or that exhibit multifunctional activity (e.g., pro-cognitive plus neuroprotective, pro-cognitive plus antipsychotic). A single compound with MTDL or multifunctional activity would circumvent 
the limitations associated with combining two or more drugs with potentially different degrees of bioavailability, pharmacokinetics, and metabolism [7] as well as simplify the dosing regimen (an advantage that could be especially important from a compliance perspective). Drug repurposing (also called drug repositioning), is another (increasingly popular) approach designed to increase the speed of the drug discovery process by identifying a new clinical use for an existing approved drug $[6,8,9]$. There are numerous cases in the past where clinical observations have led to the eventual use of drugs for purposes other than what they were originally approved for. To cite just a couple of examples; beta adrenergic receptor blockers (e.g., propranolol), originally approved for hypertension, are now are approved for congestive heart failure and migraine headache; anticonvulsant drugs (e.g., gabapentin), originally approved for epilepsy, are now used commonly for neuropathic pain and bipolar disease. It is important to note that the "clinical observation" approach to drug discovery is not an efficient mechanism for addressing unmet medical needs and there is active interest in identifying compounds for repurposing both in clinical trials as well as in the preclinical setting. Finally, the adjunctive treatment strategy (adding a second drug to an existing approved drug), while not optimal from a pharmacokinetic and compliance standpoint, is an additional alternative to improve overall treatment outcomes. This approach is commonly used in psychiatry for treatment resistant illnesses (e.g., adjunctive antipsychotic drug with an antidepressant for treatment-resistant depression).

Interesting, a variety of ligands at nicotinic acetylcholine receptors (nAChRs) appear to have the potential to fulfill one or more of these desirable categories described above (i.e., multifunctional, repurposing, or adjunctive potential). The purpose of this review, therefore, is to provide an overview of a variety of $\mathrm{nAChR}$ ligands that demonstrate potential in these categories, particularly, "multifunctional" properties. While many of the compounds discussed 
in this review may have been initially developed as part of a traditional (i.e., reductionist) drug discovery process (e.g., combinatorial chemistry and high throughput screening selected to hit a specific receptor or pathophysiologic target), follow up studies across multiple screening processes (in vitro and in vivo) suggest that they have potential as "multifunctional" compounds. Please see Table 1 for a representative list of nAChR ligands with potential as multifunctional compounds based of their positive effects across two or more therapeutic targets. Due to their densities in the mammalian brain and the amount of literature available, the review will focus on ligands of the high affinity $\alpha 4 \beta 2 \mathrm{nAChR}$ and the low affinity $\alpha 7 \mathrm{nAChR}$.

\section{2. $\alpha 4 \beta 2$ and $\alpha 7$ nicotinic acetylcholine receptors (nAChRs)}

nAChRs are ligand gated ion channels that modulate the flow of cations into and out cells, notably the influx of sodium and calcium, and the efflux of potassium. However, many (if not most) of the potential therapeutic effects of nAChR ligands have been attributed to their ability to influence neuronal excitability, synaptic plasticity, gene expression, and neurotoxicity via the regulation of intracellular calcium [184]. Neuronal nAChRs are formed through a combination of $\alpha$ and $\beta$ subunits composing heteromeric receptors, or through homomeric $\alpha$ configurations. Although there have been nine $\alpha(\alpha 2-\alpha 10)$ and three $\beta$ ( $\beta 2-\beta 4)$ subunits currently identified that can form many different combinations, as noted above, for the purposes of this review, the heteromeric $\alpha 4 \beta 2$ and homomeric $\alpha 7 \mathrm{nAChR}$ subtypes will be primarily discussed. These two nAChR receptors (see Fig 1) are the most predominant subtypes found in the mammalian brain and the most commonly targeted in drug discovery programs for neuropsychiatric disorders. $\alpha 4 \beta 2 \mathrm{nAChRs}$ possess a high affinity for acetylcholine and nicotine,

they desensitize slowly, and they are engaged in paracrine-like transmission $[10,11]$. Most likely, due to the high density of $\alpha 4 \beta 2 \mathrm{nAChRs}$ in the brain (relative to other nAChR subtypes), 
their high affinity for nicotine, as well as their previous role in reward and drug dependence, compounds active at the $\alpha 4 \beta 2$ subtype were the first to be developed for cognitive enhancement in the preclinical setting. As opposed to $\alpha 4 \beta 2 \mathrm{nAChRs}, \alpha 7 \mathrm{nAChRs}$ exhibit low affinity for acetylcholine and nicotine; they rapidly desensitize and are involved in phasic synaptic responses $[10,11]$. For several years the $\alpha 7-n A C h R$ has been considered as an especially important therapeutic target in $\mathrm{AD}$ and schizophrenia due to the deficits in $\alpha 7-\mathrm{nAChR}$ protein that have been observed in the brains of patients who suffered from these disorders [12-14]. $\alpha 7 \mathrm{nAChRs}$ are known to be abundant in the hippocampus and prefrontal cortex (important structures for cognition and AD [15]) and they modulate a number of calcium-dependent events in neurons including neurotransmitter release $[10,16]$, postsynaptic signaling $[17,18]$ and neuronal survival $[19,20]$. Moreover, agonists of $\alpha 7 \mathrm{nAChRs}$ have been shown to increase the phosphorylation of ERK and CREB (signaling pathways linked to long term potentiation and memory formation) in the rodent brain [21, 22] and to improve performance in a variety of learning and memoryrelated tasks in animals (for review, see [23]).

\section{Nicotine as a prototypic compound with "multifunctional" activity}

Interest in the prototypic tobacco alkaloid nicotine as a cognitive enhancing agent truly began nearly 25 years ago when it was first demonstrated that not only could the compound restore cognitive function in nicotine-deprived smokers, but that it could also enhance cognition in human nonsmokers and experimental animals [24]. Specific examples to support this argument now include positive effects of nicotine on working memory [25], sustained attention [26], and recognition memory [27] in rats, short term (working) memory [28] [29] and distractibility [30] in non-human primates, and multiple domains of cognition in humans including attention, information processing and short term memory [31-34]. While nicotine 
would not be classified as an antipsychotic per se, it has been shown to decrease some psychiatric symptoms in schizophrenia (particularly the negative symptoms) and to improve sensory gating and prepulse inhibition in animals and humans [35]. Interestingly, nicotine has also been shown to have neuroprotective activity in multiple disease models (i.e., both in vitro and in vivo) [36]. The mechanistic basis for the neuroprotective effects of nicotine and other nAChR ligands (see below) has not been fully elucidated, however a number of hypotheses have been proposed (based primarily on in vitro and ex vivo studies). These hypotheses include nAChR-related activation of pro-survival signaling factors such as phosphatidylinositol 3-kinase (PI3K), Akt and Bcl proteins in the brain [185], activation of calcineurin, and L-type calcium channels [184], the release of Brain-Derived Neurotrophic Factor (BDNF) and increases the cell surface expression of TrkB receptors [186], as well as the release of nerve growth factor (NGF) and increases TrkA receptors [187].

Collectively, the information cited above (which is a very short overview of an extensive body of literature) would support the argument that nicotine has potential as a multifunctional compound for a number of neuropsychiatric disorders. Unfortunately, concerns about its short half-life, cardiovascular side effects, and abuse potential have limited enthusiasm regarding the use of nicotine as a therapeutic agent to date. However, it is interesting to note, that in a recent study where nicotine was delivered via a transdermal patch to patients with Mild Cognitive Impairment (MCI), improvements in cognition were noted without the appearance of significant side effects [37].

\section{Cotinine as a prototypic compound with "multifunctional" activity}

There is now considerable evidence that the most predominant metabolite of nicotine, cotinine, might also serve as a prototypic "multifunctional" agent. This is potentially notable, 
since cotinine has advantages over nicotine including a superior safety profile [38], a much longer half-life [39] and a lower risk of abuse [40]. Studies to date indicate that cotinine might have properties that would be potentially important for the treatment of $\mathrm{AD}$, schizophrenia, and depression. For example, relevant to AD, cotinine has been shown to be cytoprotective and neuroprotective as demonstrated by its ability to improve the survival of differentiated PC12 cells deprived of nerve growth factor [40], as well as to protect primary cortical neurons from the neurotoxic effects of the amyloid beta (A $\beta)$ peptide or glutamate [41, 42]. Cotinine also improved working/short term memory in a delayed match to sample (DMTS) task in monkeys [43], prevented memory loss in an AD mouse model (Tg6799), stimulated the Akt/GSK3 $\beta$ pathway and reduced $A \beta$ aggregation in their brains [44, 45]. In studies more relevant to schizophrenia, cotinine attenuated the deficits in prepulse inhibition (PPI) of the acoustic startle response induced in three pharmacologic impairment models in rats [43], it improved sustained attention in rats that were impaired by the NMDA receptor antagonist MK-801 [46], and it attenuated deficits in working/short term memory in monkeys produced by the NMDA antagonist ketamine [47]. More recently Grizzell et al., 2014 [48] demonstrated that in mice subjected to prolonged restraint (a chronic stress model), cotinine had antidepressant-like properties and reduced cognitive impairment and synaptic loss in the hippocampus and prefrontal cortex.

\section{5. nAChR-Selective Ligands, Multifunctional Activity-Age-related cognitive decline and} Alzheimer's disease

Given the potential limitations of nicotine as a therapeutic agent (described above), drug discovery efforts to create analogs of nicotine or nicotine-like compounds began in earnest in the 1990s. Initial discovery efforts lead to the identification of the $\alpha 4 \beta 2 \mathrm{nAChR}$ agonists ABT-418 
[49] and SIB-1508Y [50] and the $\alpha 7$ nAChR agonists AR-R1779 [51] and GTS-21 (DMXBA); [52] with each nAChR subtype agonist displaying distinct neuropharmacological $[49,50,53]$; and behavioral [52, 54-59] effects thereby supporting their therapeutic potential across multiple clinical populations. Indeed, early clinical "proof-of-concept" studies with ABT-418 and GTS21 (DMXBA) showed beneficial effects on attention, cognition, and P50 auditory gating in several patient populations (i.e., ADHD, AD and schizophrenia; [32, 60-62]. While the results were encouraging, these compounds have been discontinued from further clinical development most like due to issues with their selectivity and/or side effect profiles.

With recent advances in our understanding of molecular biology and pharmacology of nAChRs, new $\alpha 4 \beta 2$ and $\alpha 7 \mathrm{nAChR}$ agonists that display chemical diversity, favorable pharmaceutical properties (e.g., pharmacokinetics and safety/tolerability) and pharmacological activity (e.g., affinity, selectivity and intrinsic activity) have been developed. This next generation of $\alpha 4 \beta 2$ nAChR agonists (e.g., ABT-089, AZD-3480 and varenicline; [63, 65, 69] and a7 nAChR agonists (e.g., ABT-107, EVP-6124, RG 3487 and TC-5619) [22, 64, 66, 67, 68] has been shown in preclinical studies to be efficacious in a variety of cognition, sensory processing and synaptic plasticity-related models. Importantly, $\alpha 7 \mathrm{nAChR}$ agonists have been shown to modulate biochemical and behavioral events associated with AD pathology [22, 70]. Moreover, several Phase 2 clinical trials with both $\alpha 4 \beta 2$ (e.g., ABT-089 and AZD-3480; [71-73] and $\alpha 7$ nAChR agonists (e.g., EVP-6124 and RG 3487) [74, 75]; have been conducted in patients with age-related memory impairments and mild to moderate AD demonstrating safety, tolerability, and positive effects across multiple cognitive domains (e.g., attention, episodic memory, working memory and executive function) using different cognitive test batteries (ADAS-Cog-13, CogState and Cognitive Drug Research Battery (CDR)). Despite the important lessons acquired 
from these clinical trials, EVP-6124 is the only compound currently undergoing Phase 3 clinical assessment for $\mathrm{AD}$ (www.forumpharma.com).

\section{6. nAChR-Selective Ligands, Multifunctional Activity-Attention-Deficit-Hyperactivity}

\section{Disorder}

Both $\alpha 4 \beta 2$ and $\alpha 7 \mathrm{nAChRs}$ in the prefrontal cortex have been implicated in attentional processes and compounds with agonist activity at these receptors are thought to have therapeutic potential in attentional disorders [76]. Nicotinic $\alpha 4 \beta 2$ and $\alpha 7 \mathrm{nAChRs}$ have been shown to differentially modulate prefrontal cortex function via their specific effects on glutamate and acetylcholine [77] as well as dopamine release [78] and thus, might be expected to possess distinctive preclinical behavioral effects [79]. Like nicotine, $\alpha 4 \beta 2$ nAChR-selective agonists (e.g., ABT-418, ABT-594, AZD-3480 and Sazetidine-A) have been shown to produce mixed results in their ability to act as "stand-alone" pro-attentional drugs, yet $\alpha 4 \beta 2 \mathrm{nAChR}$ agonists have routinely been shown to reverse pharmacologic-induced impairments (i.e., scopolamine and MK-801) in operant behavioral paradigms (e.g., 5-choice serial reaction time task (5C-SRTT) $[26,80,82,83,84,85,90]$ and visual signal detection task [81, 86 178]) measuring attentional and impulsivity processes in laboratory animals. Several lines of evidence also support a role of the $\alpha 7 \mathrm{nAChR}$ in modulating attention: (1) the observation that mice expressing genetic deletion of the $\alpha 7 \mathrm{nAChR}$ take longer to acquire stable task performance [83] and to make more omission errors compared to the wild-type controls when tested in a 5C-SRTT under increased attentional demand [83-85]. Young and colleagues [85] suggested that the increase in omissions for mice expressing genetic deletion of the $\alpha 7 \mathrm{nAChR}$ may reflect an inability to maintain attentiveness to the visual stimuli being presented during the behavioral sessions rather than a simple reduction in performance accuracy; (2) the observation that the $\alpha 7 \mathrm{nAChR}$ partial agonist RG 3487 improved 
sustained attention comparable to that of nicotine in a rat visual signal detection task [86] and the ability of RG 3487 to improve performance accuracy in an object retrieval attentional paradigm in non-human primates [87]; (3) the observation that tropisetron improved sustained visual attention (i.e., rapid visual information processing) in schizophrenic patients provides additional support for $\alpha 7 \mathrm{nAChRs}$ in human attention [88]. Despite these encouraging findings, $\alpha 7 \mathrm{nAChR}$ agonists (i.e., AR-R17779 and PNU 282987) have not shown improvement in the 5C-SRTT [89, 90]. Since RG 3487 and tropisetron are also potent 5-HT3 receptor antagonists and blockade of this receptor site also increases release of acetylcholine [78], the dual action at both $\alpha 7 \mathrm{nAChR}$ and 5-HT3 receptors may account for the observed behavioral differences. Moreover, $\alpha 4 \beta 2$ and a7 $\mathrm{nAChR}$ agonists have resulted in mixed outcomes in clinical trials of attention deficit hyperactivity disorder (ADHD) despite being well tolerated. ABT-089, AZD-3480 and ABT894 were reported to improve ADHD symptoms as measured by the Conner's Adult ADHD Rating Scale-Investigator Version (CAARS-INV) [91-93] whereas AZD 1446, $\alpha 4 \beta 2$ agonist, and TC-5619, $\alpha 7$ nAChR partial agonist, failed to significantly improve ADHD symptoms compared to placebo [94]; www.targacept.com ). Considering all of the present evidence there appears to be a role for both $\alpha 4 \beta 2$ and $\alpha 7 \mathrm{nAChRs}$ in mediating attentional processes and additional investigation is warranted especially when considering the fundamental role that attention plays in cognition and executive function.

\section{7. nAChR-Selective Ligands, Multifunctional Activity-Schizophrenia}

Schizophrenia is a debilitating psychiatric disorder characterized by positive symptoms (e.g., hallucinations, delusions), negative symptoms (e.g., depressed mood, social withdrawal) and cognitive deficits (e.g., deficits in information processing, attention, working memory, and executive function, [95]. While multiple neurotransmitter systems are likely involved in the 
etiology and pathophysiology of schizophrenia, the $\alpha 7 \mathrm{nAChR}$ has received considerable attention in schizophrenia research in the last several years. This is likely due to the identification of a mutation in chromosome 15q14 locus of CHRNA7 in schizophrenia, the associations between polymorphisms in this gene and impaired P50 auditory-evoked gating and cognitive dysfunction [96, 97], and the reduction in $\alpha 7 \mathrm{nAChR}$ density observed in the hippocampus of schizophrenics $[12,98]$ Interestingly, tobacco products are heavily abused by schizophrenics suggesting that nicotine consumption may represent an attempt to self-medicate the variety of cognitive symptoms, especially those associated with information (sensory) processing deficits and attention [99]. This hypothesis is supported by studies which show that nicotine improves auditory gating in the DBA/2 mouse [100] and in schizophrenic patients [101], and that $\alpha 7 \mathrm{nAChR}$ agonists (e.g., ABT-107, GTS-21 and tropisetron) improve auditory gating in DBA/2 mice $[59,68,102]$ as well as P50 sensory gating in schizophrenic patients $[60,88,103$, 104]. Likewise, deficits in sensorimotor gating (i.e., prepulse inhibition (PPI) of the acoustic startle) have been observed in schizophrenic patients $[105,106]$ and nicotine has been shown to normalize these deficits [106, 107], an effect blocked by the non-selective nAChR antagonist mecamylamine thus implicating nAChRs [108]. Preclinical studies of $\alpha 7 \mathrm{nAChR}$ agonists (e.g., tropisetron, SEN-12333) and partial agonists (e.g., RG-3487, TC-5619) have routinely been shown to attenuate pharmacologic-induced (e.g., apomorphine and MK-801) PPI impairments [109-112] and the effects of $\alpha 7 \mathrm{nAChR}$ agonists on sensorimotor gating appear to be receptor specific as the improved PPI response is attenuated by the $\alpha 7$ nAChR antagonist methyllycaconitine (MLA) [111]. While the sensorimotor effects of $\alpha 7 \mathrm{nAChR}$ agonists have not been directly assessed in the schizophrenic population, GTS-21 and tropisetron reversed P50 auditory-evoked sensory gating deficits in this population $[60,88,103,104]$. Despite the lack of 
a causal relationship between the sensory gating response and cognitive dysfunction [113], PPI improvements in schizophrenic patients following nicotine appear to correlate with improved prefrontal executive function [114] and further, $\alpha 7 \mathrm{nAChR}$ agonists and partial agonists that have been shown to improve sensory gating have commonly also been shown to improve cognition $[60,88,103,104]$. Collectively, this evidence suggests that sensory gating paradigms may serve as translational research tools to assess potential treatment strategies for cognitive deficits associated with schizophrenia.

There are a number of additional lines of evidence to suggest a potential for $\alpha 7 \mathrm{nAChR}$ agonists in the treatment of schizophrenia (i.e., positive effects across multiple domains of cognition that have a major impact on daily functioning $[115,116])$. For example, in preclinical studies with $\alpha 7 \mathrm{nAChR}$ agonists, robust improvements in recognition memory, working memory and executive function have been observed in young and aged rodents $[52,64,66,74,86,117]$ and non-human primates [22, 53, 87].

Additional evidence also suggests an important role of $\alpha 7 \mathrm{nAChR}$ agonists as therapeutic agents for schizophrenia. For example, NMDA antagonists have been shown to produce many of the neurochemical, behavioral and cognitive impairments associated with schizophrenia [118120] suggesting their use as pharmacological research tools. In animal models bearing resemblance to schizophrenia, $\alpha 7 \mathrm{nAChR}$ agonists have been shown to be effective in reversing the acute and chronic effects of NMDA receptor antagonists (ketamine, PCP and MK801) on learning and memory function in rodents $[74,109,112,117,121]$ and non-human primates, $[47,122]$ thereby providing a role for $\alpha 7 \mathrm{nAChRs}$ in modulating NMDA receptor function. 
Despite the extensive evidence to support the positive effects of $\alpha 7 \mathrm{nAChR}$ agonists in preclinical models of cognition, clinically, $\alpha 7 \mathrm{nAChR}$ agonists (e.g., GTS-21, tropisetron) and partial agonists (e.g., EVP-6124, RG 3487, TC-5619) have yielded mixed results in their ability to consistently meet the primary objective of cognitive improvement in schizophrenic patients [88, 104, 123-126]. However, $\alpha 7 \mathrm{nAChR}$ agonists are often effective in reducing the negative symptoms associated with schizophrenia (as measured by the Scale for the Assessment of Negative Symptoms (SANS) and the Positive and Negative Syndrome Scale (PANSS); [123, 124, 126, 127]. At present, EVP-6124 has entered into Phase 3 clinical assessment for the treatment of cognitive impairment associated with schizophrenia (www.forumpharma.com).

\section{8. nAChR Positive Allosteric Modulators-Role as Standalone and Adjunctive Treatments for Neuropsychiatric Disorders}

In addition to the development of orthosteric $\alpha 4 \beta 2$ and $\alpha 7 \mathrm{nAChR}$ agonists, nAChR positive allosteric modulators (PAMs) have been identified as a novel drug discovery approach with therapeutic opportunities across multiple targets (e.g., cognition, pain and traumatic brain injury). PAMs avoid direct receptor activation by utilizing binding sites away from the orthosteric site targeted by traditional $\alpha 4 \beta 2$ and $\alpha 7 \mathrm{nAChR}$ agonists and thus, may offer some pharmaceutical advantages. For example, in contrast to traditional nAChR agonists, PAMs require endogenous ligand (i.e., acetylcholine or choline) to elicit a $\mathrm{nAChR}$ response and thus, would maintain the natural temporal phasic stimulation pattern of the cholinergic receptor. PAMs may also reduce the likelihood of nAChR desensitization following continuous administration and maintain pharmacological activity. A potential concern, however, is that the efficacy of a PAM would be dependent on the presence of sufficient levels of endogenous cholinergic activity to elicit a therapeutic effect and with regards to dementias (e.g., AD) where 
endogenous acetylcholine levels would likely be compromised, an exogenous agonist, "promoter", might be necessary to improve cognitive function [128, 129].

To date, only a few $\alpha 4 \beta 2$ PAMs (e.g., desformylflustrabromine, LY-2087101, NS9283 and its analogue NS206) have been identified and characterized preclinically [129]. NS9283 has received the greatest preclinical attention possibly due to its receptor selectivity and brain/plasma ratio in rats [130]. NS9283 was associated with improvements in animal models of attention (i.e., 5-choice serial reaction time task), social recognition memory, spatial reference memory (PCP-deficit model) and sensorimotor gating (PCP-deficit model), effects that were sensitive to mecamylamine antagonism [130]. NS9283 has also been shown to have beneficial analgesic effects in a number of preclinical pain models (e.g., neuropathic and inflammatory pain), but only when the compound was co-administered with the $\alpha 4 \beta 2$ nAChR agonist ABT-594 [131, 132] or the $\alpha 4 \beta 2$ partial agonist NS3956 [133]. Importantly, the adverse autonomic side effects associated with ABT-594 were not enhanced by NS9283 suggesting that PAM-based approaches may widen the therapeutic window of other therapeutic compounds. A similar lack of "standalone" effect of NS9283 was also observed in the auditory discrimination task [134] and in the nicotine drug discrimination task in rats [135]. In the nicotine drug discrimination task, NS9283, but not ABT-594, failed to generalize to the interoceptive nicotine cue. However, coadministering a fixed low dose of either nicotine or ABT-594 with increasing doses of NS9283 resulted in a complete substitution for the nicotine discriminative stimulus [135]. Overall, the findings with NS9283 point to discrete differences in endogenous cholinergic levels within neural substrates responsible for mediating specific neurobiological activities (e.g., cognition vs. pain) and thus, regional cholinergic tone dictates whether the nAChR PAM will activate the nAChR channel directly ("stand-alone") or require the presence of an exogenous agonist 
("adjunctive or promoter") to produce the neurobiological response. Certainly, these distinctions will become especially important as $\alpha 4 \beta 2$ PAMs enter clinical investigations across multiple therapeutic targets (e.g., $\mathrm{AD}$, chronic pain and schizophrenia).

Discovery efforts have also identified selective $\alpha 7$ PAMs that can be categorized as either Type I or Type II modulators based on their distinct electrophysiological properties [128]. Type I PAMs (e.g., 5-hydroxyindole, NS1738 and AVL-3288) increase agonist-evoked maximum peak current amplitude and maintain desensitization response kinetics, whereas Type II PAMs (e.g., ABT-779, PNU 120596 and RO5126946) increase agonist-evoked peak amplitude but significantly reduce the rate of channel desensitization. Behaviorally, Type I PAMs (e.g., NS1738, AVL3288) have been associated with "stand-alone" improvements in recognition memory, working memory and executive function in rats [136-138] and Type I modulators have the ability to reverse scopolamine-induced deficits in the Morris water-maze task in rats [136] and in the object recognition task [139]; the latter behavioral effect blocked by $\alpha 7 \mathrm{nAChR}$ antagonism (MLA). AVL-3288 also has positive effects in the DBA/2 mouse auditory gating model [137] and interestingly, the 5-HT2B/C receptor antagonist SB-206553 which displays Type I PAM activity, restored MK-801-induced sensorimotor gating (PPI) deficits in a manner similar to the a7 nAChR agonist SSR-180711 [140].

Type II PAMs (e.g., ABT-779, PNU 120596 and RO5126946) have also been shown to improve cognition [138, 141-144] and sensory gating (auditory-evoked potentials and PPI; [140, $142,145,146]$ in animal models. Similarly, JNJ-1930942 (described as an intermediate type $\alpha 7$ PAM with characteristics falling between the profiles of Type I and Type II modulators) has beneficial effects on the auditory-evoked sensory inhibition deficits in DBA/2 mice [147]. Interestingly, Stevens and colleagues [146] recently reported that while PNU 120596 was 
efficacious in reversing the sensory gating deficits in DBA/2 mice, the modulator was inactive in C3H Chrna7 heterozygote mice which display greater decreases in hippocampal $\alpha 7 \mathrm{nAChRs}$ (50-60\%) than DBA/2 mice ( 30\%) and therefore, more closely matches the $\alpha 7 \mathrm{nAChR}$ deficits ( 50) found in post-mortem brains of schizophrenics. Briefly, C3H Chrna7 heterozygote mice were created by breeding the null mutation for the $\alpha 7 \mathrm{nAChR}$ (Chrna7) onto the $\mathrm{C} 3 \mathrm{H}$ background strain of mice [146]. In these mice, it was necessary to co-administer a low dose of choline chloride, which alone was inactive, with the test doses of PNU-120596 in order to improve the auditory sensory gating response. These data provide important insights into the lack of P50 auditory gating effect observed with JNJ-39393406 in schizophrenic patients [148] and highlights the importance of understanding the underlying neurobiological conditions associated with compromised patient populations (e.g., AD and schizophrenia) particularly when administering nAChR PAMs as therapeutic agents. Our laboratory recently demonstrated PNU 120596-related improvements in cognition in aged (cognitively-impaired) rats and aged nonhuman primates (which have been shown in other laboratories to have a variety of AD-related neurochemical deficits including decreases in hippocampal acetylcholine levels [149]. In our studies, PNU 120596 failed to improve Morris water maze performance in rats or delayedmatch-to-sample (DMTS) performance in monkeys when given alone and required the addition of a low dose of donepezil with PNU 120596 in order to improve cognitive performance [141]. Overall, the results of these studies, suggest that Type I and Type II PAMs possess therapeutic potential across multiple neurological and neuropsychiatric populations based on their preclinical efficacy at improving information processing, attention and cognition. Unfortunately, there are active clinical trials with $\alpha 7 \mathrm{nAChR}$ PAMs so we will have to wait to determine the translational 
relevance of the PAMs preclinical efficacy and any potential advantage over orthosteric $\alpha 7$ nAChR agonists.

\section{9. nAChR Ligands, Repurposing Strategies}

To date the only nicotinic ligands available as therapeutic agents (either by prescription or over the counter) are nicotine (as a gum or transdermal patch) and the $\alpha 4 \beta 2 \mathrm{nAChR}$ partial agonist varenicline and both are currently used to improve smoking cessation. There is significant evidence that each of these agents might be repurposed for other indications, however. While a detailed review of the specific literature on nicotine (as a repurposed compound) is beyond the scope of this review, there have been literally hundreds of preclinical studies designed to evaluate its potential as a therapeutic agent for conditions as diverse as AD, MCI, ADHD and schizophrenia (as noted above), as well as Parkinson disease, depression, anxiety, pain, obesity, and ulcerative colitis [150]. Some of these preclinical studies have been followed by clinical investigations with variable results.

In preclinical studies, varenicline has been shown (in rats) to improve sustained attention in a signal detection task, sensorimotor gating in a PPI task, and recognition memory in a novel object recognition task [69], thus indicating its potential for conditions such as $\mathrm{AD}$ and schizophrenia. In a study with relevance to cocaine addiction, varenicline significantly improved delayed match to sample (DMTS) performance in both cocaine-naive and cocaine-experienced monkeys [151] indicating a potential for its use in drug addiction as well as other disorders. There have been a few clinical studies designed to evaluate the effect of varenicline in schizophrenia and schizoaffective disorder [152], mild to moderate AD [153], and as adjunctive treatment with antipsychotic medications to treat cognitive impairments in schizophrenia [154]. 
While typically short in duration and with a relatively small sample size, most of the studies (with the exception of the Kim, et al. 2014 [153]) have had promising results.

\section{Differential Effects of nAChR Ligands}

As can be observed in Table 1, compounds referred to as $\mathrm{nAChR}$ agonists or partial agonists can have what appears to be quite diverse behavioral and/or physiologic effects. Some of the apparent differences may simply be due to the fact that a particular compound in question has not yet been evaluated across all of the relevant types of tasks or procedures. There are a host of other factors, however, that could contribute to real differences in responses in vivo [188, 189]. The potency and efficacy of a compound at a nAChR composed of specific subunits is important since nAChR subtypes show distinct anatomical localization and they can display markedly diverse physiological and pharmacological properties [190]. Responses secondary to the activation (or inhibition) of specific nAChRs including effects on the release of neurotransmitters and hormones may also contribute to differential responses [191]. The unique pharmacokinetic properties of a nicotinic compound, whether it generates active metabolites in vivo, and whether it has been administered acutely or chronically may also be important. As an example, nicotine has a short half-life in mammals; however, it generates a metabolite (cotinine)

that has a long half-life that has been shown to have important electrophysiological and behavioral effects [177]. Another factor that may be important is how effective a particular nAChR agonist is at desensitizing nAChRs. Interestingly, previous work has indicated that desensitization of nAChRs may in fact be an important component of a compounds efficacy as a pro-cognitive agent [47]. Another important factor (noted above in section 6) is whether the compound has activity at receptors for neurotransmitters other than acetylcholine such as 
serotonin 5-HT3, as is the case for many compounds that also have activity at $\alpha 7$ nAChRs (e.g., tropisetron [78]).

\section{Summary and Conclusions}

The currently available treatments for neurologic and psychiatric illness such as AD and schizophrenia remain inadequate despite the decades of research devoted to novel drug discovery and development. While the original intent of developing $\mathrm{AChR}$ ligands for neuropsychiatric disorders may have followed the traditional reductionist approach (e.g., the creation of selective ligands at specific nAChR subtypes for the treatment of cognitive deficits) in neuropsychiatric disorders, there is now considerable evidence that a number of these compounds may exhibit additional features that would qualify them as "multifunctional" agents. By possessing procognitive as well as antipsychotic-like activity and/or neuroprotective actions, some of these agents may have the potential to not only treat several key symptoms of neuropsychiatric disorders, but they could also have potential to modify the disease outcome. Other studies suggest that nicotinic PAMs might be effective either alone or as adjunctive agents to be combined with currently available treatments to enhance therapeutic efficacy. Finally, there is

considerable evidence to suggest that the clinically available nAChR ligands, nicotine and varenicline could be repurposed for several indications beyond smoking cessation.

\section{Acknowledgments}

The authors would like to thank Ms. Ashley Davis for her administrative assistance in preparing this article. This corresponding author's laboratories are supported by the National Institute on Drug Abuse (DA029127), the National Institute of Environmental Health Sciences (ES012241), and the Department of Defense/US Army Medical Research Acquisition Activity 
(USAMRAA) W81XWH-12-1-0536. The corresponding author has also provided consultation or performed research (relevant to this article) in the last three years either contractually or in collaboration with several pharmaceutical companies including AbbVie Inc., Institut de Recherches Servier, and Comentis, Inc. 


\section{References}

[1] Paul SM, Mytelka DS, Dunwiddie CT, Persinger CC, Munos BH, Lindborg SR, et al. How to improve R\&D productivity: the pharmaceutical industry's grand challenge. Nat Rev Drug Discov. 2010;9:203-14.

[2] Insel TR, Sahakian BJ. Drug research: a plan for mental illness. Nature. 2012;483:269.

[3] Chandler DJ. Something's got to give: psychiatric disease on the rise and novel drug development on the decline. Drug Discov Today. 2013;18:202-6.

[4] Reaume AG. Drug repurposing through nonhypothesis driven phenotypic screening. Drug Discovery Today: Therapeutic Strategies. 2011;8:85-8.

[5] Maggiora GM. The reductionist paradox: are the laws of chemistry and physics sufficient for the discovery of new drugs? J Comput Aided Mol Des. 2011;25:699-708.

[6] Medina-Franco JL, Giulianotti MA, Welmaker GS, Houghten RA. Shifting from the single to the multitarget paradigm in drug discovery. Drug Discov Today. 2013;18:495-501.

[7] Youdim MB, Buccafusco JJ. Multi-functional drugs for various CNS targets in the treatment of neurodegenerative disorders. Trends Pharmacol Sci. 2005;26:27-35.

[8] Ashburn TT, Thor KB. Drug repositioning: identifying and developing new uses for existing drugs. Nat Rev Drug Discov. 2004;3:673-83.

[9] Merino A, Bronowska AK, Jackson DB, Cahill DJ. Drug profiling: knowing where it hits. Drug Discov Today. 2010;15:749-56.

[10] Descarries L, Gisiger V, Steriade M. Diffuse transmission by acetylcholine in the CNS. Prog Neurobiol. 1997;53:603-25.

[11] Albuquerque EX, Pereira EF, Alkondon M, Rogers SW. Mammalian nicotinic acetylcholine receptors: from structure to function. Physiol Rev. 2009;89:73-120.

[12] Freedman R, Hall M, Adler LE, Leonard S. Evidence in postmortem brain tissue for decreased numbers of hippocampal nicotinic receptors in schizophrenia. Biological psychiatry. 1995;38:22-33.

[13] Burghaus L, Schutz U, Krempel U, de Vos RA, Jansen Steur EN, Wevers A, et al. Quantitative assessment of nicotinic acetylcholine receptor proteins in the cerebral cortex of Alzheimer patients. Brain research Molecular brain research. 2000;76:385-8.

[14] Guan ZZ, Zhang X, Ravid R, Nordberg A. Decreased protein levels of nicotinic receptor subunits in the hippocampus and temporal cortex of patients with Alzheimer's disease. Journal of neurochemistry. 2000;74:237-43.

[15] Gotti C, Moretti M, Gaimarri A, Zanardi A, Clementi F, Zoli M. Heterogeneity and complexity of native brain nicotinic receptors. Biochem Pharmacol. 2007;74:1102-11.

[16] McGehee DS, Heath MJ, Gelber S, Devay P, Role LW. Nicotine enhancement of fast excitatory synaptic transmission in CNS by presynaptic receptors. Science. 1995;269:1692-6.

[17] Chang KT, Berg DK. Nicotinic acetylcholine receptors containing alpha7 subunits are required for reliable synaptic transmission in situ. J Neurosci. 1999;19:3701-10. 
[18] Hefft S, Hulo S, Bertrand D, Muller D. Synaptic transmission at nicotinic acetylcholine receptors in rat hippocampal organotypic cultures and slices. The Journal of physiology. 1999;515 ( Pt 3):769-76.

[19] Messi ML, Renganathan M, Grigorenko E, Delbono O. Activation of alpha7 nicotinic acetylcholine receptor promotes survival of spinal cord motoneurons. FEBS letters. 1997;411:328 .

[20] Berger F, Gage FH, Vijayaraghavan S. Nicotinic receptor-induced apoptotic cell death of hippocampal progenitor cells. The Journal of neuroscience : the official journal of the Society for Neuroscience. 1998;18:6871-81.

[21] Bitner RS, Bunnelle WH, Anderson DJ, Briggs CA, Buccafusco J, Curzon P, et al. Broadspectrum efficacy across cognitive domains by alpha7 nicotinic acetylcholine receptor agonism correlates with activation of ERK1/2 and CREB phosphorylation pathways. The Journal of neuroscience : the official journal of the Society for Neuroscience. 2007;27:10578-87.

[22] Bitner RS, Bunnelle WH, Decker MW, Drescher KU, Kohlhaas KL, Markosyan S, et al. In vivo pharmacological characterization of a novel selective alpha7 neuronal nicotinic acetylcholine receptor agonist ABT-107: preclinical considerations in Alzheimer's disease. The Journal of pharmacology and experimental therapeutics. 2010;334:875-86.

[23] Kem WR. The brain alpha7 nicotinic receptor may be an important therapeutic target for the treatment of Alzheimer's disease: studies with DMXBA (GTS-21). Behavioural brain research. 2000;113:169-81.

[24] Levin ED, McClernon FJ, Rezvani AH. Nicotinic effects on cognitive function: behavioral characterization, pharmacological specification, and anatomic localization. Psychopharmacology. 2006;184:523-39.

[25] Levin ED, Simon BB. Nicotinic acetylcholine involvement in cognitive function in animals. Psychopharmacology. 1998;138:217-30.

[26] Mirza NR, Stolerman IP. Nicotine enhances sustained attention in the rat under specific task conditions. Psychopharmacology. 1998;138:266-74.

[27] Puma C, Deschaux O, Molimard R, Bizot JC. Nicotine improves memory in an object recognition task in rats. European neuropsychopharmacology : the journal of the European College of Neuropsychopharmacology. 1999;9:323-7.

[28] Elrod K, Buccafusco JJ, Jackson WJ. Nicotine enhances delayed matching-to-sample performance by primates. Life sciences. 1988;43:277-87.

[29] Buccafusco JJ, Jackson WJ. Beneficial effects of nicotine administered prior to a delayed matching-to-sample task in young and aged monkeys. Neurobiol Aging. 1991;12:233-8.

[30] Prendergast MA, Jackson WJ, Terry AV, Jr., Kille NJ, Arneric SP, Decker MW, et al. Agerelated differences in distractibility and response to methylphenidate in monkeys. Cerebral cortex. 1998;8:164-72.

[31] White HK, Levin ED. Four-week nicotine skin patch treatment effects on cognitive performance in Alzheimer's disease. Psychopharmacology. 1999;143:158-65. 
[32] Newhouse PA, Kelton M. Nicotinic systems in central nervous systems disease: degenerative disorders and beyond. Pharmaceutica acta Helvetiae. 2000;74:91-101.

[33] Min SK, Moon IW, Ko RW, Shin HS. Effects of transdermal nicotine on attention and memory in healthy elderly non-smokers. Psychopharmacology. 2001;159:83-8.

[34] Sahakian B, Jones G, Levy R, Gray J, Warburton D. The effects of nicotine on attention, information processing, and short-term memory in patients with dementia of the Alzheimer type. The British journal of psychiatry : the journal of mental science. 1989;154:797-800.

[35] Kumari V, Postma P. Nicotine use in schizophrenia: the self medication hypotheses. Neuroscience and biobehavioral reviews. 2005;29:1021-34.

[36] Picciotto MR, Zoli M. Neuroprotection via nAChRs: the role of nAChRs in neurodegenerative disorders such as Alzheimer's and Parkinson's disease. Frontiers in bioscience: a journal and virtual library. 2008;13:492-504.

[37] Newhouse P, Kellar K, Aisen P, White H, Wesnes K, Coderre E, et al. Nicotine treatment of mild cognitive impairment: a 6-month double-blind pilot clinical trial. Neurology. 2012;78:91101.

[38] Hatsukami DK, Grillo M, Pentel PR, Oncken C, Bliss R. Safety of cotinine in humans: physiologic, subjective, and cognitive effects. Pharmacology, biochemistry, and behavior. 1997;57:643-50.

[39] Benowitz NL. Pharmacology of nicotine: addiction and therapeutics. Annual review of pharmacology and toxicology. 1996;36:597-613.

[40] Rosecrans JA. Nicotine as a discriminative stimulus to behavior: its characterization and relevance to smoking behavior. NIDA research monograph. 1979:58-69.

[41] Burgess S, Zeitlin R, Echeverria V. Cotinine inhibits amyloid- $\beta$ peptide neurotoxicity and oligomerization. J Clinic Toxicol S. 2011;6.

[42] Gao J, Adam B-L, Terry AV. Evaluation of nicotine and cotinine analogs as potential neuroprotective agents for Alzheimer's disease. Bioorganic \& medicinal chemistry letters. 2014;24:1472-8.

[43] Terry AV, Hernandez CM, Hohnadel EJ, Bouchard KP, Buccafusco JJ. Cotinine, a neuroactive metabolite of nicotine: potential for treating disorders of impaired cognition. CNS drug reviews. 2005;11:229-52.

[44] Echeverria V, Zeitlin R, Burgess S, Patel S, Barman A, Thakur G, et al. Cotinine reduces amyloid-beta aggregation and improves memory in Alzheimer's disease mice. Journal of Alzheimer's disease : JAD. 2011;24:817-35.

[45] Patel S, Grizzell JA, Holmes R, Zeitlin R, Solomon R, Sutton TL, et al. Cotinine halts the advance of Alzheimer's disease-like pathology and associated depressive-like behavior in Tg6799 mice. Frontiers in aging neuroscience. 2014;6:162.

[46] Terry AV, Jr., Buccafusco JJ, Schade RF, Vandenhuerk L, Callahan PM, Beck WD, et al. The nicotine metabolite, cotinine, attenuates glutamate (NMDA) antagonist-related effects on the performance of the five choice serial reaction time task (5C-SRTT) in rats. Biochemical pharmacology. 2012;83:941-51. 
[47] Buccafusco JJ, Terry AV, Jr. A reversible model of the cognitive impairment associated with schizophrenia in monkeys: potential therapeutic effects of two nicotinic acetylcholine receptor agonists. Biochemical pharmacology. 2009;78:852-62.

[48] Grizzell JA, Mullins M, Iarkov A, Rohani A, Charry LC, Echeverria V. Cotinine reduces depressive-like behavior and hippocampal vascular endothelial growth factor downregulation after forced swim stress in mice. Behavioral neuroscience. 2014;128:713-21.

[49] Arneric SP, Sullivan JP, Briggs CA, Donnelly-Roberts D, Anderson DJ, Raszkiewicz JL, et al. (S)-3-methyl-5-(1-methyl-2-pyrrolidinyl) isoxazole (ABT 418): a novel cholinergic ligand with cognition-enhancing and anxiolytic activities: I. In vitro characterization. The Journal of pharmacology and experimental therapeutics. 1994;270:310-8.

[50] Cosford ND, Bleicher L, Herbaut A, McCallum JS, Vernier JM, Dawson H, et al. (S)-(-)-5ethynyl-3-(1-methyl-2-pyrrolidinyl)pyridine maleate (SIB-1508Y): a novel anti-parkinsonian agent with selectivity for neuronal nicotinic acetylcholine receptors. Journal of medicinal chemistry. 1996;39:3235-7.

[51] Mullen G, Napier J, Balestra M, DeCory T, Hale G, Macor J, et al. (-)-Spiro[1azabicyclo[2.2.2] octane-3,5'-oxazolidin-2'-one], a conformationally restricted analogue of acetylcholine, is a highly selective full agonist at the alpha 7 nicotinic acetylcholine receptor. Journal of medicinal chemistry. 2000;43:4045-50.

[52] Arendash GW, Sengstock GJ, Sanberg PR, Kem WR. Improved learning and memory in aged rats with chronic administration of the nicotinic receptor agonist GTS-21. Brain research. 1995;674:252-9.

[53] Briggs CA, Anderson DJ, Brioni JD, Buccafusco JJ, Buckley MJ, Campbell JE, et al. Functional characterization of the novel neuronal nicotinic acetylcholine receptor ligand GTS-21 in vitro and in vivo. Pharmacology, biochemistry, and behavior. 1997;57:231-41.

[54] Decker MW, Brioni JD, Sullivan JP, Buckley MJ, Radek RJ, Raszkiewicz JL, et al. (S)-3methyl-5-(1-methyl-2-pyrrolidinyl)isoxazole (ABT 418): a novel cholinergic ligand with cognition-enhancing and anxiolytic activities: II. In vivo characterization. The Journal of pharmacology and experimental therapeutics. 1994;270:319-28.

[55] Ferguson SM, Brodkin JD, Lloyd GK, Menzaghi F. Antidepressant-like effects of the subtype-selective nicotinic acetylcholine receptor agonist, SIB-1508Y, in the learned helplessness rat model of depression. Psychopharmacology. 2000;152:295-303.

[56] Levin ED, Bettegowda C, Blosser J, Gordon J. AR-R17779, and alpha7 nicotinic agonist, improves learning and memory in rats. Behavioural pharmacology. 1999;10:675-80.

[57] Prendergast MA, Jackson WJ, Terry AV, Jr., Decker MW, Arneric SP, Buccafusco JJ. Central nicotinic receptor agonists ABT-418, ABT-089, and (-)-nicotine reduce distractibility in adult monkeys. Psychopharmacology. 1998;136:50-8.

[58] Schneider JS, Tinker JP, Van Velson M, Menzaghi F, Lloyd GK. Nicotinic acetylcholine receptor agonist SIB-1508Y improves cognitive functioning in chronic low-dose MPTP-treated monkeys. The Journal of pharmacology and experimental therapeutics. 1999;290:731-9.

[59] Stevens KE, Kem WR, Mahnir VM, Freedman R. Selective alpha7-nicotinic agonists normalize inhibition of auditory response in DBA mice. Psychopharmacology. 1998;136:320-7. 
[60] Olincy A, Harris JG, Johnson LL, Pender V, Kongs S, Allensworth D, et al. Proof-ofconcept trial of an alpha7 nicotinic agonist in schizophrenia. Archives of general psychiatry. 2006;63:630-8.

[61] Potter A, Corwin J, Lang J, Piasecki M, Lenox R, Newhouse PA. Acute effects of the selective cholinergic channel activator (nicotinic agonist) ABT-418 in Alzheimer's disease. Psychopharmacology. 1999;142:334-42.

[62] Wilens TE, Biederman J, Spencer TJ, Bostic J, Prince J, Monuteaux MC, et al. A pilot controlled clinical trial of ABT-418, a cholinergic agonist, in the treatment of adults with attention deficit hyperactivity disorder. The American journal of psychiatry. 1999;156:1931-7.

[63] Decker MW, Bannon AW, Curzon P, Gunther KL, Brioni JD, Holladay MW, et al. ABT089 [2-methyl-3-(2-(S)-pyrrolidinylmethoxy)pyridine dihydrochloride]: II. A novel cholinergic channel modulator with effects on cognitive performance in rats and monkeys. The Journal of pharmacology and experimental therapeutics. 1997;283:247-58.

[64] Hauser TA, Kucinski A, Jordan KG, Gatto GJ, Wersinger SR, Hesse RA, et al. TC-5619: an alpha7 neuronal nicotinic receptor-selective agonist that demonstrates efficacy in animal models of the positive and negative symptoms and cognitive dysfunction of schizophrenia. Biochemical pharmacology. 2009;78:803-12.

[65] Obinu MC, Reibaud M, Miquet JM, Pasquet M, Rooney T. Brain-selective stimulation of nicotinic receptors by TC-1734 enhances ACh transmission from frontoparietal cortex and memory in rodents. Progress in neuro-psychopharmacology \& biological psychiatry. 2002;26:913-8.

[66] Prickaerts J, van Goethem NP, Chesworth R, Shapiro G, Boess FG, Methfessel C, et al. EVP-6124, a novel and selective alpha7 nicotinic acetylcholine receptor partial agonist, improves memory performance by potentiating the acetylcholine response of alpha 7 nicotinic acetylcholine receptors. Neuropharmacology. 2012;62:1099-110.

[67] Wallace TL, Callahan PM, Tehim A, Bertrand D, Tombaugh G, Wang S, et al. RG3487, a novel nicotinic alpha7 receptor partial agonist, improves cognition and sensorimotor gating in rodents. The Journal of pharmacology and experimental therapeutics. 2011;336:242-53.

[68] Radek RJ, Robb HM, Stevens KE, Gopalakrishnan M, Bitner RS. Effects of the novel alpha7 nicotinic acetylcholine receptor agonist ABT-107 on sensory gating in DBA/2 mice: pharmacodynamic characterization. The Journal of pharmacology and experimental therapeutics. 2012;343:736-45.

[69] Rollema H, Hajos M, Seymour PA, Kozak R, Majchrzak MJ, Guanowsky V, et al. Preclinical pharmacology of the alpha4beta2 nAChR partial agonist varenicline related to effects on reward, mood and cognition. Biochemical pharmacology. 2009;78:813-24.

[70] Sadigh-Eteghad S, Talebi M, Mahmoudi J, Babri S, Shanehbandi D. Selective activation of alpha7 nicotinic acetylcholine receptor by PHA-543613 improves Abeta25-35-mediated cognitive deficits in mice. Neuroscience. 2015;298:81-93.

[71] Dunbar GC, Kuchibhatla RV, Lee G. A randomized double-blind study comparing 25 and $50 \mathrm{mg}$ TC-1734 (AZD3480) with placebo, in older subjects with age-associated memory impairment. Journal of psychopharmacology. 2011;25:1020-9. 
[72] Frolich L, Ashwood T, Nilsson J, Eckerwall G. Effects of AZD3480 on cognition in patients with mild-to-moderate Alzheimer's disease: a phase IIb dose-finding study. Journal of Alzheimer's disease : JAD. 2011;24:363-74.

[73] Lenz RA, Pritchett YL, Berry SM, Llano DA, Han S, Berry DA, et al. Adaptive, Dosefinding Phase 2 Trial Evaluating the Safety and Efficacy of ABT-089 in Mild to Moderate Alzheimer Disease. Alzheimer disease and associated disorders. 2015.

[74] Wallace TL, Porter RH. Targeting the nicotinic alpha7 acetylcholine receptor to enhance cognition in disease. Biochemical pharmacology. 2011;82:891-903.

[75] Deardorff WJ, Shobassy A, Grossberg GT. Safety and clinical effects of EVP-6124 in subjects with Alzheimer's disease currently or previously receiving an acetylcholinesterase inhibitor medication. Expert review of neurotherapeutics. 2015;15:7-17.

[76] Wallace TL, Bertrand D. Importance of the nicotinic acetylcholine receptor system in the prefrontal cortex. Biochemical pharmacology. 2013;85:1713-20.

[77] Parikh V, Ji J, Decker MW, Sarter M. Prefrontal beta2 subunit-containing and alpha7 nicotinic acetylcholine receptors differentially control glutamatergic and cholinergic signaling. The Journal of neuroscience : the official journal of the Society for Neuroscience. 2010;30:351830.

[78] Huang M, Felix AR, Kwon S, Lowe D, Wallace T, Santarelli L, et al. The alpha-7 nicotinic receptor partial agonist/5-HT3 antagonist RG3487 enhances cortical and hippocampal dopamine and acetylcholine release. Psychopharmacology. 2014;231:2199-210.

[79] Callahan PM, Terry AV, Jr. Attention. Handbook of experimental pharmacology. 2015;228:161-89.

[80] Howe WM, Ji J, Parikh V, Williams S, Mocaer E, Trocme-Thibierge C, et al. Enhancement of attentional performance by selective stimulation of alpha4beta2 $\left(^{*}\right)$ nAChRs: underlying cholinergic mechanisms. Neuropsychopharmacology : official publication of the American College of Neuropsychopharmacology. 2010;35:1391-401.

[81] McGaughy J, Decker MW, Sarter M. Enhancement of sustained attention performance by the nicotinic acetylcholine receptor agonist ABT-418 in intact but not basal forebrain-lesioned rats. Psychopharmacology. 1999;144:175-82.

[82] Mohler EG, Franklin SR, Rueter LE, Fox GB, Decker MW, Browman KE. ABT-594 improves performance in the 5-choice serial reaction time task under conditions of increased difficulty, sub-chronic dosing, and in poorly-performing subjects. Pharmacology, biochemistry, and behavior. 2010;95:146-57.

[83] Young JW, Finlayson K, Spratt C, Marston HM, Crawford N, Kelly JS, et al. Nicotine improves sustained attention in mice: evidence for involvement of the alpha7 nicotinic acetylcholine receptor. Neuropsychopharmacology : official publication of the American College of Neuropsychopharmacology. 2004;29:891-900.

[84] Hoyle E, Genn RF, Fernandes C, Stolerman IP. Impaired performance of alpha7 nicotinic receptor knockout mice in the five-choice serial reaction time task. Psychopharmacology. 2006;189:211-23. 
[85] Young JW, Crawford N, Kelly JS, Kerr LE, Marston HM, Spratt C, et al. Impaired attention is central to the cognitive deficits observed in alpha 7 deficient mice. European neuropsychopharmacology : the journal of the European College of Neuropsychopharmacology. 2007; 17:145-55.

[86] Rezvani AH, Kholdebarin E, Brucato FH, Callahan PM, Lowe DA, Levin ED. Effect of R3487/MEM3454, a novel nicotinic alpha7 receptor partial agonist and 5-HT3 antagonist on sustained attention in rats. Progress in neuro-psychopharmacology \& biological psychiatry. 2009;33:269-75.

[87] Wallace-Boone TL CG, Dao H, Lowe DA, Porter R, Santarelli L. R3487/MEM3454, a novel nicotinic alpha 7 receptor partial agonist, improves attention and working memory performance in cynomolgus macaques. Society for Neuroscience2009.

[88] Shiina A, Shirayama Y, Niitsu T, Hashimoto T, Yoshida T, Hasegawa T, et al. A randomised, double-blind, placebo-controlled trial of tropisetron in patients with schizophrenia. Annals of general psychiatry. 2010;9:27.

[89] Grottick AJ, Higgins GA. Effect of subtype selective nicotinic compounds on attention as assessed by the five-choice serial reaction time task. Behavioural brain research. 2000;117:197208.

[90] Young JW, Meves JM, Geyer MA. Nicotinic agonist-induced improvement of vigilance in mice in the 5-choice continuous performance test. Behavioural brain research. 2013;240:119-33.

[91] Apostol G, Abi-Saab W, Kratochvil CJ, Adler LA, Robieson WZ, Gault LM, et al. Efficacy and safety of the novel alpha(4)beta(2) neuronal nicotinic receptor partial agonist ABT-089 in adults with attention-deficit/hyperactivity disorder: a randomized, double-blind, placebocontrolled crossover study. Psychopharmacology. 2012;219:715-25.

[92] Bain EE, Robieson W, Pritchett Y, Garimella T, Abi-Saab W, Apostol G, et al. A randomized, double-blind, placebo-controlled phase 2 study of alpha4beta2 agonist ABT-894 in adults with ADHD. Neuropsychopharmacology : official publication of the American College of Neuropsychopharmacology. 2013;38:405-13.

[93] Potter AS, Dunbar G, Mazzulla E, Hosford D, Newhouse PA. AZD3480, a novel nicotinic receptor agonist, for the treatment of attention-deficit/hyperactivity disorder in adults. Biological psychiatry. 2014;75:207-14.

[94] Jucaite A, Ohd J, Potter AS, Jaeger J, Karlsson P, Hannesdottir K, et al. A randomized, double-blind, placebo-controlled crossover study of alpha4beta $2 *$ nicotinic acetylcholine receptor agonist AZD1446 (TC-6683) in adults with attention-deficit/hyperactivity disorder. Psychopharmacology. 2014;231:1251-65.

[95] Green MF, Braff DL. Translating the basic and clinical cognitive neuroscience of schizophrenia to drug development and clinical trials of antipsychotic medications. Biological psychiatry. 2001;49:374-84.

[96] Adler LE, Olincy A, Waldo M, Harris JG, Griffith J, Stevens K, et al. Schizophrenia, sensory gating, and nicotinic receptors. Schizophrenia bulletin. 1998;24:189-202.

[97] Freedman R, Leonard S. Genetic linkage to schizophrenia at chromosome 15q14. American journal of medical genetics. 2001;105:655-7. 
[98] Gothelf D, Soreni N, Nachman RP, Tyano S, Hiss Y, Reiner O, et al. Evidence for the involvement of the hippocampus in the pathophysiology of schizophrenia. European neuropsychopharmacology : the journal of the European College of Neuropsychopharmacology. 2000;10:389-95.

[99] Olincy A, Young DA, Freedman R. Increased levels of the nicotine metabolite cotinine in schizophrenic smokers compared to other smokers. Biological psychiatry. 1997;42:1-5.

[100] Stevens KE, Wear KD. Normalizing effects of nicotine and a novel nicotinic agonist on hippocampal auditory gating in two animal models. Pharmacology, biochemistry, and behavior. 1997;57:869-74.

[101] Adler LE, Hoffer LD, Wiser A, Freedman R. Normalization of auditory physiology by cigarette smoking in schizophrenic patients. The American journal of psychiatry. 1993;150:1856-61.

[102] Hashimoto K, Iyo M, Freedman R, Stevens KE. Tropisetron improves deficient inhibitory auditory processing in DBA/2 mice: role of alpha 7 nicotinic acetylcholine receptors. Psychopharmacology. 2005;183:13-9.

[103] Koike K, Hashimoto K, Takai N, Shimizu E, Komatsu N, Watanabe H, et al. Tropisetron improves deficits in auditory P50 suppression in schizophrenia. Schizophrenia research. 2005;76:67-72.

[104] Zhang XY, Liu L, Liu S, Hong X, Chen da C, Xiu MH, et al. Short-term tropisetron treatment and cognitive and P50 auditory gating deficits in schizophrenia. The American journal of psychiatry. 2012;169:974-81.

[105] Braff DL, Geyer MA, Swerdlow NR. Human studies of prepulse inhibition of startle: normal subjects, patient groups, and pharmacological studies. Psychopharmacology. 2001;156:234-58.

[106] Kumari V, Soni W, Sharma T. Influence of cigarette smoking on prepulse inhibition of the acoustic startle response in schizophrenia. Human psychopharmacology. 2001;16:321-6.

[107] Hong LE, Wonodi I, Lewis J, Thaker GK. Nicotine effect on prepulse inhibition and prepulse facilitation in schizophrenia patients. Neuropsychopharmacology : official publication of the American College of Neuropsychopharmacology. 2008;33:2167-74.

[108] George TP, Termine A, Sacco KA, Allen TM, Reutenauer E, Vessicchio JC, et al. A preliminary study of the effects of cigarette smoking on prepulse inhibition in schizophrenia: involvement of nicotinic receptor mechanisms. Schizophrenia research. 2006;87:307-15.

[109] Callahan PM, Terry AV, Jr., Tehim A. Effects of the nicotinic alpha7 receptor partial agonist GTS-21 on NMDA-glutamatergic receptor related deficits in sensorimotor gating and recognition memory in rats. Psychopharmacology. 2014;231:3695-706.

[110] Ghiron C, Haydar SN, Aschmies S, Bothmann H, Castaldo C, Cocconcelli G, et al. Novel alpha-7 nicotinic acetylcholine receptor agonists containing a urea moiety: identification and characterization of the potent, selective, and orally efficacious agonist 1-[6-(4fluorophenyl)pyridin-3-yl]-3-(4-piperidin-1-ylbutyl) urea (SEN34625/WYE-103914). Journal of medicinal chemistry. 2010;53:4379-89. 
[111] Kohnomi S, Suemaru K, Goda M, Choshi T, Hibino S, Kawasaki H, et al. Ameliorating effects of tropisetron on dopaminergic disruption of prepulse inhibition via the alpha(7) nicotinic acetylcholine receptor in Wistar rats. Brain research. 2010;1353:152-8.

[112] Roncarati R, Scali C, Comery TA, Grauer SM, Aschmi S, Bothmann H, et al. Procognitive and neuroprotective activity of a novel alpha7 nicotinic acetylcholine receptor agonist for treatment of neurodegenerative and cognitive disorders. The Journal of pharmacology and experimental therapeutics. 2009;329:459-68.

[113] Swerdlow NR, Light GA, Cadenhead KS, Sprock J, Hsieh MH, Braff DL. Startle gating deficits in a large cohort of patients with schizophrenia: relationship to medications, symptoms, neurocognition, and level of function. Archives of general psychiatry. 2006;63:1325-35.

[114] Rabin RA, Sacco KA, George TP. Correlation of prepulse inhibition and Wisconsin Card Sorting Test in schizophrenia and controls: effects of smoking status. Schizophrenia research. 2009;114:91-7.

[115] Aleman A, Hijman R, de Haan EH, Kahn RS. Memory impairment in schizophrenia: a meta-analysis. The American journal of psychiatry. 1999;156:1358-66.

[116] Ranganath C, Minzenberg MJ, Ragland JD. The cognitive neuroscience of memory function and dysfunction in schizophrenia. Biological psychiatry. 2008;64:18-25.

[117] Pichat P, Bergis OE, Terranova JP, Urani A, Duarte C, Santucci V, et al. SSR180711, a novel selective alpha7 nicotinic receptor partial agonist: (II) efficacy in experimental models predictive of activity against cognitive symptoms of schizophrenia. Neuropsychopharmacology : official publication of the American College of Neuropsychopharmacology. 2007;32:17-34.

[118] de Lima MN, Laranja DC, Bromberg E, Roesler R, Schroder N. Pre- or post-training administration of the NMDA receptor blocker MK-801 impairs object recognition memory in rats. Behavioural brain research. 2005;156:139-43.

[119] Lahti AC, Weiler MA, Tamara Michaelidis BA, Parwani A, Tamminga CA. Effects of ketamine in normal and schizophrenic volunteers. Neuropsychopharmacology : official publication of the American College of Neuropsychopharmacology. 2001;25:455-67.

[120] Malhotra AK, Pinals DA, Adler CM, Elman I, Clifton A, Pickar D, et al. Ketamineinduced exacerbation of psychotic symptoms and cognitive impairment in neuroleptic-free schizophrenics. Neuropsychopharmacology : official publication of the American College of Neuropsychopharmacology. 1997;17:141-50.

[121] Hashimoto K, Ishima T, Fujita Y, Matsuo M, Kobashi T, Takahagi M, et al. Phencyclidine-induced cognitive deficits in mice are improved by subsequent subchronic administration of the novel selective alpha7 nicotinic receptor agonist SSR180711. Biological psychiatry. 2008;63:92-7.

[122] Cannon CE, Puri V, Vivian JA, Egbertson MS, Eddins D, Uslaner JM. The nicotinic alpha7 receptor agonist GTS-21 improves cognitive performance in ketamine impaired rhesus monkeys. Neuropharmacology. 2013;64:191-6.

[123] Freedman R, Olincy A, Buchanan RW, Harris JG, Gold JM, Johnson L, et al. Initial phase 2 trial of a nicotinic agonist in schizophrenia. The American journal of psychiatry. 2008;165:1040-7. 
[124] Lieberman JA, Dunbar G, Segreti AC, Girgis RR, Seoane F, Beaver JS, et al. A randomized exploratory trial of an alpha-7 nicotinic receptor agonist (TC-5619) for cognitive enhancement in schizophrenia. Neuropsychopharmacology : official publication of the American College of Neuropsychopharmacology. 2013;38:968-75.

[125] Preskorn SH, Gawryl M, Dgetluck N, Palfreyman M, Bauer LO, Hilt DC. Normalizing effects of EVP-6124, an alpha-7 nicotinic partial agonist, on event-related potentials and cognition: a proof of concept, randomized trial in patients with schizophrenia. Journal of psychiatric practice. 2014;20:12-24.

[126] Umbricht D, Keefe RS, Murray S, Lowe DA, Porter R, Garibaldi G, et al. A randomized, placebo-controlled study investigating the nicotinic alpha7 agonist, RG3487, for cognitive deficits in schizophrenia. Neuropsychopharmacology : official publication of the American College of Neuropsychopharmacology. 2014;39:1568-77.

[127] Noroozian M, Ghasemi S, Hosseini SM, Modabbernia A, Khodaie-Ardakani MR, Mirshafiee $\mathrm{O}$, et al. A placebo-controlled study of tropisetron added to risperidone for the treatment of negative symptoms in chronic and stable schizophrenia. Psychopharmacology. 2013;228:595-602.

[128] Bertrand D, Gopalakrishnan M. Allosteric modulation of nicotinic acetylcholine receptors. Biochem Pharmacol. 2007;74:1155-63.

[129] Grupe M, Grunnet M, Bastlund JF, Jensen AA. Targeting alpha4beta2 nicotinic acetylcholine receptors in central nervous system disorders: perspectives on positive allosteric modulation as a therapeutic approach. Basic \& clinical pharmacology \& toxicology. 2015;116:187-200.

[130] Timmermann DB, Sandager-Nielsen K, Dyhring T, Smith M, Jacobsen AM, Nielsen EO, et al. Augmentation of cognitive function by NS9283, a stoichiometry-dependent positive allosteric modulator of alpha2- and alpha4-containing nicotinic acetylcholine receptors. British journal of pharmacology. 2012;167:164-82.

[131] Lee CH, Zhu C, Malysz J, Campbell T, Shaughnessy T, Honore P, et al. $\alpha 4 \beta 2$ neuronal nicotinic receptor positive allosteric modulation: an approach for improving the therapeutic index of $\alpha 4 \beta 2$ nAChR agonists in pain. Biochem Pharmacol. 2011;82:959-66.

[132] Zhu CZ, Chin CL, Rustay NR, Zhong C, Mikusa J, Chandran P, et al. Potentiation of analgesic efficacy but not side effects: co-administration of an alpha4beta2 neuronal nicotinic acetylcholine receptor agonist and its positive allosteric modulator in experimental models of pain in rats. Biochemical pharmacology. 2011;82:967-76.

[133] Rode F, Munro G, Holst D, Nielsen EO, Troelsen KB, Timmermann DB, et al. Positive allosteric modulation of alpha4beta2 nAChR agonist induced behaviour. Brain research. 2012;1458:67-75.

[134] Grupe M, Grunnet M, Laursen B, Bastlund JF. Neuropharmacological modulation of the P3-like event-related potential in a rat two-tone auditory discrimination task with modafinil and NS9283, a positive allosteric modulator of alpha4beta2 nAChRs. Neuropharmacology. 2014;79:444-55. 
[135] Mohler EG, Franklin SR, Rueter LE. Discriminative-stimulus effects of NS9283, a nicotinic $\alpha 4 \beta 2^{*}$ positive allosteric modulator, in nicotine-discriminating rats. Psychopharmacology (Berl). 2014;231:67-74.

[136] Timmermann DB, Gronlien JH, Kohlhaas KL, Nielsen EO, Dam E, Jorgensen TD, et al. An allosteric modulator of the alpha7 nicotinic acetylcholine receptor possessing cognitionenhancing properties in vivo. The Journal of pharmacology and experimental therapeutics. 2007;323:294-307.

[137] Ng HJ, Whittemore ER, Tran MB, Hogenkamp DJ, Broide RS, Johnstone TB, et al. Nootropic alpha7 nicotinic receptor allosteric modulator derived from GABAA receptor modulators. Proceedings of the National Academy of Sciences of the United States of America. 2007;104:8059-64.

[138] Nikiforuk A, Kos T, Potasiewicz A, Popik P. Positive allosteric modulation of alpha 7 nicotinic acetylcholine receptors enhances recognition memory and cognitive flexibility in rats. European neuropsychopharmacology: the journal of the European College of Neuropsychopharmacology. 2015.

[139] Hogenkamp DJ, Ford-Hutchinson TA, Li WY, Whittemore ER, Yoshimura RF, Tran MB, et al. Design, synthesis, and activity of a series of arylpyrid-3-ylmethanones as type I positive allosteric modulators of alpha7 nicotinic acetylcholine receptors. Journal of medicinal chemistry. 2013;56:8352-65.

[140] Dunlop J, Lock T, Jow B, Sitzia F, Grauer S, Jow F, et al. Old and new pharmacology: positive allosteric modulation of the alpha7 nicotinic acetylcholine receptor by the 5hydroxytryptamine(2B/C) receptor antagonist SB-206553 (3,5-dihydro-5-methyl-N-3pyridinylbenzo[1,2-b:4,5-b']di pyrrole-1(2H)-carboxamide). The Journal of pharmacology and experimental therapeutics. 2009;328:766-76.

[141] Callahan PM, Hutchings EJ, Kille NJ, Chapman JM, Terry AV, Jr. Positive allosteric modulator of alpha7 nicotinic-acetylcholine receptors, PNU-120596 augments the effects of donepezil on learning and memory in aged rodents and non-human primates. Neuropharmacology. 2013;67:201-12.

[142] Kohlhaas KL, Bitner RS, Gopalakrishnan M, Rueter LE. Effects of alpha7 nicotinic acetylcholine receptor agonists on antipsychotic efficacy in a preclinical mouse model of psychosis. Psychopharmacology. 2012;220:823-33.

[143] McLean SL, Idris NF, Grayson B, Gendle DF, Mackie C, Lesage AS, et al. PNU-120596, a positive allosteric modulator of alpha7 nicotinic acetylcholine receptors, reverses a sub-chronic phencyclidine-induced cognitive deficit in the attentional set-shifting task in female rats. Journal of psychopharmacology. 2012;26:1265-70.

[144] Sahdeo S, Wallace T, Hirakawa R, Knoflach F, Bertrand D, Maag H, et al. Characterization of RO5126946, a Novel $\alpha 7$ nicotinic acetylcholine receptor-positive allosteric modulator. J Pharmacol Exp Ther. 2014;350:455-68.

[145] Hurst RS, Hajos M, Raggenbass M, Wall TM, Higdon NR, Lawson JA, et al. A novel positive allosteric modulator of the alpha7 neuronal nicotinic acetylcholine receptor: in vitro and in vivo characterization. The Journal of neuroscience : the official journal of the Society for Neuroscience. 2005;25:4396-405. 
[146] Stevens KE, Zheng L, Floyd KL, Stitzel JA. Maximizing the effect of an alpha7 nicotinic receptor PAM in a mouse model of schizophrenia-like sensory inhibition deficits. Brain research. 2015;1611:8-17.

[147] Dinklo T, Shaban H, Thuring JW, Lavreysen H, Stevens KE, Zheng L, et al. Characterization of 2-[[4-fluoro-3-(trifluoromethyl)phenyl]amino]-4-(4-pyridinyl)-5thiazolemethanol (JNJ-1930942), a novel positive allosteric modulator of the \{alpha\}7 nicotinic acetylcholine receptor. The Journal of pharmacology and experimental therapeutics. 2011;336:560-74.

[148] Winterer G, Gallinat J, Brinkmeyer J, Musso F, Kornhuber J, Thuerauf N, et al. Allosteric alpha-7 nicotinic receptor modulation and P50 sensory gating in schizophrenia: a proof-ofmechanism study. Neuropharmacology. 2013;64:197-204.

[149] Quirion R, Wilson A, Rowe W, Aubert I, Richard J, Doods H, et al. Facilitation of acetylcholine release and cognitive performance by an $\mathrm{M}(2)$-muscarinic receptor antagonist in aged memory-impaired. The Journal of neuroscience : the official journal of the Society for Neuroscience. 1995;15:1455-62.

[150] Powledge TM. Nicotine as therapy. PLoS biology. 2004;2:e404.

[151] Gould RW, Garg PK, Garg S, Nader MA. Effects of nicotinic acetylcholine receptor agonists on cognition in rhesus monkeys with a chronic cocaine self-administration history. Neuropharmacology. 2013;64:479-88.

[152] Smith RC, Lindenmayer JP, Davis JM, Cornwell J, Noth K, Gupta S, et al. Cognitive and antismoking effects of varenicline in patients with schizophrenia or schizoaffective disorder. Schizophrenia research. 2009;110:149-55.

[153] Kim SY, Choi SH, Rollema H, Schwam EM, McRae T, Dubrava S, et al. Phase II crossover trial of varenicline in mild-to-moderate Alzheimer's disease. Dementia and geriatric cognitive disorders. 2014;37:232-45.

[154] Shim JC, Jung DU, Jung SS, Seo YS, Cho DM, Lee JH, et al. Adjunctive varenicline treatment with antipsychotic medications for cognitive impairments in people with schizophrenia: a randomized double-blind placebo-controlled trial. Neuropsychopharmacology : official publication of the American College of Neuropsychopharmacology. 2012;37:660-8.

[155] Donnelly-Roberts DL, Xue IC, Arneric SP, Sullivan JP. In vitro neuroprotective properties of the novel cholinergic channel activator (ChCA), ABT-418. Brain Res. 1996;719:36-44.

[156] Prendergast MA, Terry AV, Jackson WJ, Marsh KC, Decker MW, Arneric SP, et al. Improvement in accuracy of delayed recall in aged and non-aged, mature monkeys after intramuscular or transdermal administration of the CNS nicotinic receptor agonist ABT-418. Psychopharmacology (Berl). 1997;130:276-84.

[157] Stevens KE, Wear KD. Normalizing effects of nicotine and a novel nicotinic agonist on hippocampal auditory gating in two animal models. Pharmacol Biochem Behav. 1997;57:869-74.

[158] Buccafusco JJ, Terry AV, Decker MW, Gopalakrishnan M. Profile of nicotinic acetylcholine receptor agonists ABT-594 and A-582941, with differential subtype selectivity, on delayed matching accuracy by young monkeys. Biochem Pharmacol. 2007;74:1202-11. 
[159] Donnelly-Roberts DL, Puttfarcken PS, Kuntzweiler TA, Briggs CA, Anderson DJ, Campbell JE, et al. ABT-594 [(R)-5-(2-azetidinylmethoxy)-2-chloropyridine]: a novel, orally effective analgesic acting via neuronal nicotinic acetylcholine receptors: I. In vitro characterization. J Pharmacol Exp Ther. 1998;285:777-86.

[160] Rowbotham MC, Arslanian A, Nothaft W, Duan WR, Best AE, Pritchett Y, et al. Efficacy and safety of the $\alpha 4 \beta 2$ neuronal nicotinic receptor agonist ABT-894 in patients with diabetic peripheral neuropathic pain. Pain. 2012;153:862-8.

[161] Mazurov AA, Miao L, Bhatti BS, Strachan JP, Akireddy S, Murthy S, et al. Discovery of 3-(5-chloro-2-furoyl)-3,7-diazabicyclo[3.3.0]octane (TC-6683, AZD1446), a novel highly selective $\alpha 4 \beta 2$ nicotinic acetylcholine receptor agonist for the treatment of cognitive disorders. J Med Chem. 2012;55:9181-94.

[162] Szeliga K, Jordan K, Hauser T, Mazurov A, Yohannes D, Rezvani A, et al. AZD1446 (TC6683), a novel alpha4beta 2 nAChR agonist with cognitive-enhancing properties. Society for Neuroscience2012.

[163] Schneider JS, Tinker JP, Van Velson M, Menzaghi F, Lloyd GK. Nicotinic acetylcholine receptor agonist SIB-1508Y improves cognitive functioning in chronic low-dose MPTP-treated monkeys. J Pharmacol Exp Ther. 1999;290:731-9.

[164] Bordia T, McGregor M, Papke RL, Decker MW, McIntosh JM, Quik M. The $\alpha 7$ nicotinic receptor agonist ABT-107 protects against nigrostriatal damage in rats with unilateral 6hydroxydopamine lesions. Exp Neurol. 2015;263:277-84.

[165] Van Kampen M, Selbach K, Schneider R, Schiegel E, Boess F, Schreiber R. AR-R 17779 improves social recognition in rats by activation of nicotinic alpha7 receptors. Psychopharmacology (Berl). 2004;172:375-83.

[166] Pitsikas N, Borsini F. Different effects of tropisetron and ondansetron in learning and memory paradigms. Pharmacol Biochem Behav. 1997;56:571-6.

[167] Spilman P, Descamps O, Gorostiza O, Peters-Libeu C, Poksay KS, Matalis A, et al. The multi-functional drug tropisetron binds APP and normalizes cognition in a murine Alzheimer's model. Brain Res. 2014;1551:25-44.

[168] Sawyer J, Eaves EL, Heyser CJ, Maswood S. Tropisetron, a 5-HT(3) receptor antagonist, enhances object exploration in intact female rats. Behav Pharmacol. 2012;23:806-9.

[169] Hernandez CM, Gearhart DA, Parikh V, Hohnadel EJ, Davis LW, Middlemore ML, et al. Comparison of galantamine and donepezil for effects on nerve growth factor, cholinergic markers, and memory performance in aged rats. J Pharmacol Exp Ther. 2006;316:679-94.

[170] Hohnadel E, Bouchard K, Terry AV, Jr. Galantamine and donepezil attenuate pharmacologically induced deficits in prepulse inhibition in rats. Neuropharmacology. 2007;52:542-51.

[171] Williams DK, Wang J, Papke RL. Positive allosteric modulators as an approach to nicotinic acetylcholine receptor-targeted therapeutics: advantages and limitations. Biochem Pharmacol. 2011;82:915-30.

[172] Sullivan JP, Donnelly-Roberts D, Briggs CA, Anderson DJ, Gopalakrishnan M, Xue IC, et al. ABT-089 [2-methyl-3-(2-(S)-pyrrolidinylmethoxy)pyridine]: I. A potent and selective 
cholinergic channel modulator with neuroprotective properties. J Pharmacol Exp Ther. 1997;283:235-46.

[173] Rueter LE, Anderson DJ, Briggs CA, Donnelly-Roberts DL, Gintant GA, Gopalakrishnan M, et al. ABT-089: pharmacological properties of a neuronal nicotinic acetylcholine receptor agonist for the potential treatment of cognitive disorders. CNS Drug Rev. 2004;10:167-82.

[174] Menze ET, Esmat A, Tadros MG, Abdel-Naim AB, Khalifa AE. Genistein improves 3NPA-induced memory impairment in ovariectomized rats: impact of its antioxidant, antiinflammatory and acetylcholinesterase modulatory properties. PLoS One. 2015 Feb 12;10(2):e0117223.

[175] Buccafusco, J.J. and Terry, A.V., Jr.: The potential role of cotinine in the cognitive and neuroprotective actions of nicotine. Invited Minireview, Life Sciences 2003;72:2931-42.

[176] Buccafusco JJ, Terry AV Jr. A reversible model of the cognitive impairment associated with schizophrenia in monkeys: potential therapeutic effects of two nicotinic acetylcholine receptor agonists. Biochemical Pharmacology 2009;78:852-62.

[177] Terry AV, Callahan PM, Bertrand D. R-(+) - and S-(-) - Isomers of Cotinine Augment Cholinergic Responses in vitro and in vivo. Journal of Pharmacology and Experimental Therapeutics 2015;352:405-18.

[178] Rezvani AH1, Cauley M, Xiao Y, Kellar KJ, Levin ED. Effects of chronic sazetidine-A, a selective $\alpha 4 \beta 2$ neuronal nicotinic acetylcholine receptors desensitizing agent on pharmacologically-induced impaired attention in rats. Psychopharmacology (Berl). 2013; 226(1):35-43.

[179] Cucchiaro G, Xiao Y, Gonzalez-Sulser A, Kellar KJ. Analgesic effects of Sazetidine-A, a new nicotinic cholinergic drug. Anesthesiology. 2008;109(3):512-9.

[180] Turner JR, Castellano LM, Blendy JA. Nicotinic partial agonists varenicline and sazetidine-A have differential effects on affective behavior. J Pharmacol Exp Ther. 2010; 334(2):665-72.

[181] Lippiello P, Letchworth SR, Gatto GJ, Traina VM, Bencherif M. Ispronicline: a novel alpha4beta2 nicotinic acetylcholine receptor-selective agonist with cognition-enhancing and neuroprotective properties. J Mol Neurosci. 2006; 30(1-2):19-20.

[182] Gatto GJ, Bohme GA, Caldwell WS, Letchworth SR, Traina VM, Obinu MC, Laville M, Reibaud M, Pradier L, Dunbar G, Bencherif M. TC-1734: an orally active neuronal nicotinic acetylcholine receptor modulator with antidepressant, neuroprotective and long-lasting cognitive effects. CNS Drug Rev. 2004 Summer;10(2):147-66

[183] Kumari V, Postma P. Nicotine use in schizophrenia: the self medication hypotheses. Neurosci Biobehav Rev. 2005; 29(6):1021-34. 
[184] Stevens TR, Krueger SR, Fitzsimonds RM, Picciotto MR Neuroprotection by nicotine in mouse primary cortical cultures involves activation of calcineurin and L-type calcium channel inactivation. J Neurosci. 2003; 5;23(31):10093-9

[185] Kawamata J, Shimohama S. Stimulating nicotinic receptors trigger multiple pathways attenuating cytotoxicity in models of Alzheimer's and Parkinson's diseases. J Alzheimers Dis. 2011; 24 Suppl 2:95-109.

[186] Serres F, Carney SL. Nicotine regulates SH-SY5Y neuroblastoma cell proliferation through the release of brain-derived neurotrophic factor. Brain Res. 2006; 26;1101(1):36-42.

[187] Formaggio E, Fazzini F, Dalfini AC, Di Chio M, Cantù C, Decimo I, et al. Nicotine increases the expression of neurotrophin receptor tyrosine kinase receptor $\mathrm{A}$ in basal forebrain cholinergic neurons. Neuroscience. 2010 17;166(2):580-9.

[188] Brioni JD, Decker MW, Sullivan JP, Arneric SP. The pharmacology of (-)-nicotine and novel cholinergic channel modulators. Adv Pharmacol. 1997; 37:153-214.

[189] Marks MJ, Whiteaker P, Calcaterra J, Stitzel JA, Bullock AE, Grady SR, et al. Two pharmacologically distinct components of nicotinic receptor-mediated rubidium efflux in mouse brain require the beta2 subunit. J Pharmacol Exp Ther. 1999; 289(2):1090-103.

[190] Sargent PB. The diversity of neuronal nicotinic acetylcholine receptors. Annual Review of Neuroscience. 1993; 16:403-443

[191] Wonnacott S. Presynaptic nicotinic ACh receptors. Trends Neurosci. 1997; 20(2):92-8.

[192] Levin ED. Nicotinic Receptors in the Nervous System. E.D. Levin (Ed.) CRC Press: Boca Raton, 2001.

[193] Dani JA, Bertrand D. Nicotinic acetylcholine receptors and nicotinic cholinergic mechanisms of the central nervous system. Annu Rev Pharmacol Toxicol. 2007; 47:699-729.

[194] Taly A, Corringer PJ, Guedin D, Lestage P, Changeux JP. Nicotinic receptors: allosteric transitions and therapeutic targets in the nervous system. Nat Rev Drug Discov. 2009; 8(9):73350 . 


\section{Figure Legends}

Fig 1. Diagram illustrating potential "multifunctional" activities (e.g., pro-cognitive, antipsychotic-like, and neuroprotective effects) of ligands of the heteromeric, high affinity $\alpha 4 \beta 2$ nAChR and the homomeric, low affinity $\alpha 7 \mathrm{nAChR}$. These subtypes are the two most abundant nAChRs found in the mammalian brain. Both receptors consist of five subunits arranged around a central channel that opens when endogenous ligands such as acetylcholine (ACh) or exogenous ligands (nicotine) bind at the orthosteric site allowing cations to flow through the channel into the neuron causing depolarization. Allosteric sites are the target of positive allosteric modulators (PAMs) and they are located at a site which is distinct from the orthosteric where they serve to indirectly influence (modulate) the effects of the agonist. The $\alpha 7 \mathrm{nAChR}$ is composed of five $\alpha 7$ subunits and the $\alpha 4 \beta 2 \mathrm{nAChR}$ is composed of two $\alpha 4$ subunits and three $\beta 2$ subunits. The $\alpha 4 \beta 2$ nAChR allows passage of both calcium $\left(\mathrm{Ca}^{++}\right)$and sodium $\left(\mathrm{Na}^{+}\right)$ions, whereas the $\alpha 7 \mathrm{nAChR}$ principally allows passage of calcium ions. In neurons, most $\alpha 4 \beta 2$ and $\alpha 7 \mathrm{nAChRs}$ are found at

presynaptic sites, however they can be also found at both postsynaptic, perisynaptic and somatodendritic sites. Moreover, both subtypes can be found on cholinergic, dopaminergic, noradrenergic, GABAergic, glutamatergic, and other neuronal phenotypes [191, 192, 193, 194]. 


\begin{tabular}{|c|c|c|c|c|c|}
\hline Compound Name & $\begin{array}{l}\text { nAChR } \\
\text { subtype }\end{array}$ & Receptor Effect & Cognitive Domain Enhanced & $\begin{array}{l}\text { Additional } \\
\text { Properties }\end{array}$ & References \\
\hline ABT-418 & $\alpha 4 \beta 2$ & agonist & $\begin{array}{l}\text { attention, working memory, spatial learning, } \\
\text { associative learning }\end{array}$ & $\begin{array}{l}\text { Analgesic, } \\
\text { Neuroprotective } \\
\text { (glutamate } \\
\text { excitotoxicity) }\end{array}$ & $49,54,57,155$ \\
\hline ABT-594 & $\alpha 4 \beta 2$ & agonist & attention, working memory & analgesic & $82,158,159$ \\
\hline ABT-894 & $\alpha 4 \beta 2$ & agonist & attention, executive function & analgesic & 94,160 \\
\hline AZD 1446 (TC-8863) & $\alpha 4 \beta 2$ & agonist & $\begin{array}{l}\text { attention, working memory, spatial } \\
\text { learning/memory }\end{array}$ & & 161,162 \\
\hline SIB-1508Y & $\alpha 4 \beta 2$ & agonist & $\begin{array}{l}\text { attention, short-term memory, working } \\
\text { memory }\end{array}$ & Antidepressant & 55,58 \\
\hline Sazetidine-A & $\alpha 4 \beta 2$ & $\begin{array}{l}\text { agonist, 'silent } \\
\text { desensitizer' }\end{array}$ & attention & $\begin{array}{l}\text { analgesic, } \\
\text { antidepressant }\end{array}$ & $178,179,180$ \\
\hline NS9283 & $\alpha 4 \beta 2$ & PAM & $\begin{array}{l}\text { attention, social recognition, spatial reference } \\
\text { memory }\end{array}$ & $\begin{array}{l}\text { Sensorimotor } \\
\text { gating }\end{array}$ & 130 \\
\hline AZD-3480 (TC-1734) & $\alpha 4 \beta 2$ & partial agonist & $\begin{array}{l}\text { attention, episodic memory, working } \\
\text { memory and executive function }\end{array}$ & $\begin{array}{l}\text { neuroprotective } \\
\text { (glutamate), } \\
\text { antidepressant }\end{array}$ & 181,182 \\
\hline Varenicline & $\alpha 4 \beta 2$ & $\begin{array}{l}\text { partial agonist }(+\alpha 7 \\
\text { agonist) }\end{array}$ & $\begin{array}{l}\text { attention, recognition memory, working } \\
\text { memory }\end{array}$ & & 69,151 \\
\hline ABT-107 & $\alpha 7$ & agonist & $\begin{array}{l}\text { attention, episodic, working and recognition } \\
\text { memory, executive function }\end{array}$ & $\begin{array}{l}\text { Neuroprotective } \\
\text { (6-OHDA lesion } \\
\text { model), sensory } \\
\text { gating }\end{array}$ & $21,22,164$ \\
\hline AR-R1779 & $\alpha 7$ & agonist & working memory, social recognition, & & $51,56,165$ \\
\hline GTS-21 (DMXBA) & $\alpha 7$ & $\begin{array}{l}\text { partial agonist (+ weak } \\
\alpha 4 \beta 2 \text { antagonist) }\end{array}$ & $\begin{array}{l}\text { associative learning, working memory, } \\
\text { recognition memory }\end{array}$ & $\begin{array}{l}\text { P50 sensory } \\
\text { gating }\end{array}$ & $23,47,109$ \\
\hline
\end{tabular}




\begin{tabular}{|c|c|c|c|c|c|}
\hline SEN-12333 & $\alpha 7$ & agonist & $\begin{array}{l}\text { attention, episodic, object and memory, } \\
\text { executive function }\end{array}$ & $\begin{array}{l}\text { Neuroprotective } \\
\text { (quisqualate } \\
\text { lesion model), } \\
\text { Sensorimotor } \\
\text { gating (PPI) }\end{array}$ & 112 \\
\hline Tropisetron & $\alpha 7$ & $\begin{array}{l}\text { partial agonist }(+5 \mathrm{HT} 3 \\
\text { antagonist) }\end{array}$ & $\begin{array}{l}\text { attention, recognition memory, spatial } \\
\text { learning }\end{array}$ & $\begin{array}{l}\text { Sensorimotor } \\
\text { gating }(\mathrm{PPI})\end{array}$ & $\begin{array}{l}88,102,103, \\
111,166,167, \\
168\end{array}$ \\
\hline EVP-6124 & $\alpha 7$ & $\begin{array}{l}\text { partial agonist }(+5 \mathrm{HT} 3 \\
\text { antagonist) }\end{array}$ & $\begin{array}{l}\text { attention, episodic memory, working } \\
\text { memory and executive function }\end{array}$ & & 66 \\
\hline TC-5619 & $\alpha 7$ & agonist & $\begin{array}{l}\text { attention, recognition memory, executive } \\
\text { function }\end{array}$ & $\begin{array}{l}\text { Sensorimotor } \\
\text { gating (PPI) }\end{array}$ & 64,124 \\
\hline RG 3487 & $\alpha 7$ & $\begin{array}{l}\text { partial agonist }(+5 \mathrm{HT} 3 \\
\text { antagonist) }\end{array}$ & $\begin{array}{l}\text { attention, spatial learning, episodic, } \\
\text { recognition and working memory, executive } \\
\text { function }\end{array}$ & $\begin{array}{l}\text { Sensorimotor } \\
\text { gating }(\mathrm{PPI})\end{array}$ & 67 \\
\hline JNJ-39393406 & $\alpha 7$ & mixed Type I \& II PAM & $\begin{array}{l}\text { attention, recognition memory, executive } \\
\text { function }\end{array}$ & sensory gating & 148 \\
\hline AVL-3288 & $\alpha 7$ & Type I PAM & $\begin{array}{l}\text { episodic recognition memory, working } \\
\text { memory and executive function }\end{array}$ & $\begin{array}{l}\text { Neuroprotective } \\
\text { (glutamate } \\
\text { excitotoxicity, } \\
\text { amyloid- } \beta \text { ), } \\
\text { Sensory gating }\end{array}$ & 137 \\
\hline Galantamine & $\alpha 7$ & Type I PAM + AChEI & $\begin{array}{l}\text { attention, recognition memory, cognitive } \\
\text { flexibility, spatial learning }\end{array}$ & $\begin{array}{l}\text { Sensorimotor } \\
\text { gating (PPI) }\end{array}$ & $\begin{array}{l}138,169,170, \\
171\end{array}$ \\
\hline Genistein & $\alpha 7$ & Type I PAM & associative learning & $\begin{array}{l}\text { neuroprotective } \\
\text { (3-Nitropropionic } \\
\text { acid model) }\end{array}$ & 171,174 \\
\hline NS1738 & $\alpha 7$ & Type I PAM & $\begin{array}{l}\text { recognition memory, spatial learning, } \\
\text { working memory and executive function }\end{array}$ & & 136,171 \\
\hline PNU 120596 & $\alpha 7$ & Type II PAM & $\begin{array}{l}\text { recognition memory, spatial learning, } \\
\text { working memory, cognitive flexibility }\end{array}$ & Sensory gating & $138,141,146$ \\
\hline
\end{tabular}




\begin{tabular}{|l|l|l|l|l|l|}
\hline Cotinine & $\alpha 7$ & sensitizer & $\begin{array}{l}\text { attention, recognition memory, working } \\
\text { memory, executive function }\end{array}$ & $\begin{array}{l}\text { Neuroprotective } \\
\text { (amyloid), } \\
\text { Sensorimotor } \\
\text { gating (PPI) }\end{array}$ & $\begin{array}{l}\text { 41, 42, 43, 46, } \\
175,176,177\end{array}$ \\
\hline Nicotine & & & & \\
& $\alpha 4 \beta 2+$ & agonist & $\begin{array}{l}\text { attention, working memory, recognition } \\
\text { memory }\end{array}$ & $\begin{array}{l}\text { Neuroprotective } \\
\text { (amyloid), } \\
\text { Sensorimotor } \\
\text { gating (PPI) }\end{array}$ & $\begin{array}{l}25,26,27,28, \\
29,30,36,183\end{array}$ \\
\hline ABT-089 & $\begin{array}{l}\alpha 4 \beta 2+ \\
\alpha 6 \beta 2\end{array}$ & $\begin{array}{l}\alpha 4 \beta 2 \text { agonist }+\alpha 6 \beta 2 \\
\text { partial agonist }\end{array}$ & $\begin{array}{l}\text { attention, episodic memory, working } \\
\text { memory, spatial learning, executive function } \\
\text { (glutamate } \\
\text { excitotoxicity) }\end{array}$ & 38, 172, 173 \\
\hline
\end{tabular}




\section{nAChR Ligands}

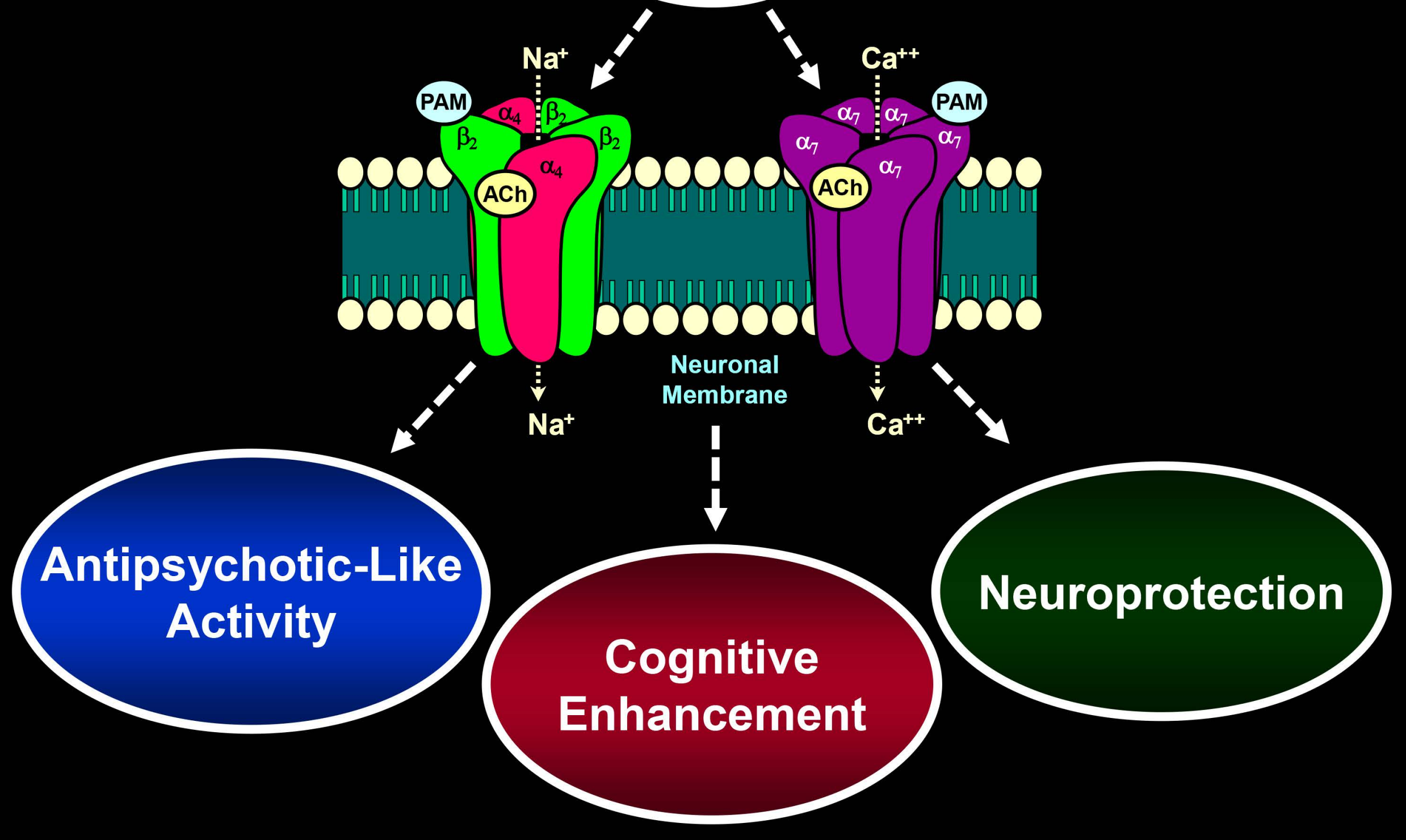




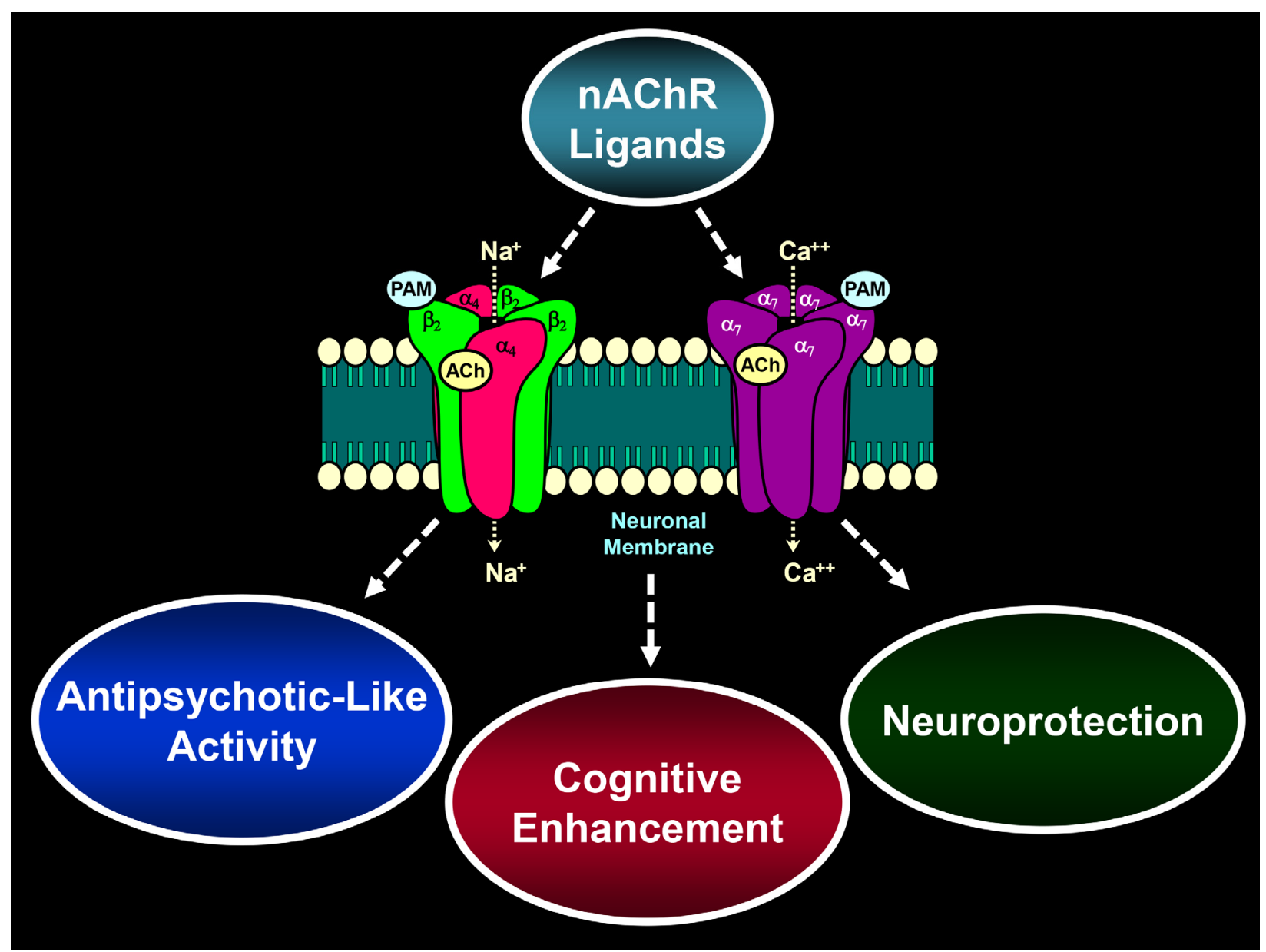

